\title{
A szeizmikus reflexiós módszerek szerepe a nem szénhidrogénipari kutatásokban Magyarországon — Példák a Magyar Bányászati és Földtani Szolgálat és elődei tevékenységéből
}

\author{
CSERKÉSZ-NAGy Ágnes, BAUER Márton, TAKÁCs Ernő, CSABAFI Róbert, Gúthy Tibor, KóBorné Bujdosó Éva, \\ TÖRÖK István, †REDLERnÉ TÁTRAi Marianna, SzŐTS Gergely, KovÁCs Attila Csaba, Hegedús Endre \\ Magyar Bányászati és Földtani Szolgálat, Alkalmazott Geofizikai Osztály \\ cserkesz-nagy.agnes@mbfsz.gov.hu, bauer.marton@mbfsz.gov.hu, takacs.erno@mbfsz.gov.hu, csabafi.robert@mbfsz.gov.hu, \\ guthy.tibor@mbfsz.gov.hu,bujdoso.eva@mbfsz.gov.hu, torok.istvan@mbfsz.gov.hu, szots.gergely@gmail.com, kacs74@gmail.com, \\ hegedus.endre@mbfsz.gov.hu
}

\section{Significance of the reflection seismic methods in the non-hydrocarbon explorations in Hungary- Case studies from the the Mining and Geological Survey of Hungary and its predecessors}

Abstract

Applied seismic research at the Mining and Geological Survey of Hungary follows the traditions of the Eötvös Loránd Geophysical Institute in conformity with the recent demands. Utilising the joint interpretation of archive geoscience data and modern seismic results, the risk of geological investigation can be efficiently reduced and the obtained geological models contributes to the success of innovation projects connected with the geological environment. The highest uncertainty in such projects (e.g. exploitation of natural resources, waste deposition, or construction geology) is the delimitation of the geological formations and the characterisation of their petrophysical properties and inhomogeneities. If only point-like borehole data were used for mapping, the above tasks could be performed only with a high level of uncertainty.

In this paper, three case studies are presented from Hungary. The results demonstrate the benefits of the seismic investigations in decreasing the geological uncertainty at low cost compared to the total budget of the project.

The requirement for establishing the proposed high-activity radioactive waste depository in the Western Mecsek Mountains is that the target geological formation, the Boda Claystone Formation (BAF) must correspond with strictly specified parameters (extent, thickness, and spatial position). Based on the new seismic results, the outlines of the BAF was extended towards the west, the structural lineaments articulating the study area were refined, and the significance of the Middle- Miocene compressional phase was confirmed.

The production and injection wells of the geothermal project of the city of Győr were located based on a multi-step seismic survey carried out around the villages of Pér and Böny. The key for the cost-effectiveness of the project, regarding the geological setting of the area (fractured, karstic carbonate water reservoir) was the mapping of deep and laterally narrow fault zones with a proper permeability. High-resolution 2D and 3D surveys provided detailed structural information for determining the optimal locations of the wells.

The least known geological features of the Western Borsod Coal Province around the village of Sajómercse are the faults which represent the highest risk from economical viewpoint. A new shallow seismic survey performed in 2019 verified the existence of the faults supposed by high-resolution well log correlations, and shed light on the fault kinematics. Beyond the dominantly extensional tectonics the seismic section shows transpressional tectonics in the study area. In addition, several smaller, previously unknown faults were detected with a throw comparable to the thickness of coal seams.

Keywords: high-resolution reflection seismics, tectonic investigation, geothermal, coal exploration, geological uncertainty

Összefoglalás

Az Eötvös Loránd Geofizikai Intézet kutatási hagyományait megőrizve a Magyar Bányászati és Földtani Szolgálat (MBFSZ) jelenleg is végez alkalmazott szeizmikus kutatásokat a mai igényekhez alkalmazkodva. Az archív földtani adatok és az új szeizmikus mérési eredmények együttes értelmezésével hatékonyan csökkenthetô a kutatási fázis (rövidtávú) földtani kockázata, így az ezek segítségével kialakított földtani modell jelentôs mértékben hozzájárulhat a földtani közeget érintő beruházások sikerességéhez. Az ilyen jellegú beruházásoknál, legyenek azok nyersanyagtermeléssel, hulladékelhelyezéssel vagy akár építésföldtannal kapcsolatosak, a legnagyobb bizonytalanságot az egyes földtani képződmények lehatárolása, kőzetfizikai állapotának, inhomogenitásának meghatározása jelenti. Ezek térképezése pontszerú fúrási adatok alapján csak nagyfokú bizonytalanság mellett tehető meg. 
Jelen munkában három magyarországi esettanulmányt ismertetünk, melyeknél kézzelfogható, hogy a projektek teljes költségvetéséhez képest kis kutatási költségeket jelentő szeizmikus méréseknek milyen pozitív hatása van a földtani bizonytalanság csökkentésében.

A Nyugat-Mecsek területén tervezett nagyaktivitású radioaktívhulladék-tároló létesítésének feltétele, hogy a megcélzott földtani közeg, a Bodai Agyagkő Formáció (BAF) kiterjedése, vastagsága és térbeli pozíciója a tervezett paramétereknek megfeleljen. Az új szeizmikus eredmények alapján a BAF elterjedésének nyugati határa módosult, a területet tagoló szerkezeti elemek lefutása pontosítható volt, illetve megerősítést nyert az intenzív középső-miocén kompressziós események jelentősége.

A győri geotermikus projekt Pér-Bőny környéki geotermikus kútpárjai egy többlépcsős szeizmikus kutatás eredményeként kerültek lemélyítésre. A projekt gazdaságosságának kulcsa a repedezett, karsztosodott karbonátos víztartóban a megfelelő vízadó képességú, jelentős mélységú, de laterálisan korlátozott méretű vetőzónák kitérképezése volt, melyhez a fokozatosan közelítő 2D és 3D szeizmikus mérések szolgáltattak lokális, részletező szerkezeti ismereteket.

A nyugat-borsodi sajómercsei szénterület földtanában a legkevésbé ismert, így gazdasági szempontból a legnagyobb kockázatot jelentő elemek a vetők. A 2019-es kismélységú szeizmikus kutatás keretében a korábbi nagyfelbontású karotázskorreláció alapján feltételezett vetôk bizonyítást nyertek, kinematikájuk tisztázódott: az alapvetően extenziós tektonika mellett a szeizmikus szelvény transzpressziós tektonika jelenlétére is utal. Továbbá számos olyan kisebb, de a széntelepek vastagságával összemérhetô elvetésú vetőt sikerült kimutatni, melyek létezése eddig ismeretlen volt.

Tárgyszavak: nagyfelbontású reflexiós szeizmika, szerkezetkutatás, geotermia, szénkutatás, földtani kockázat

\section{Bevezetés}

A geológiai képződményeket érintő beruházások, legyenek azok akár ásványvagyon-, illetve energiakitermeléssel, akár a felszín alatti térrészben történő elhelyezéssel kapcsolatosak, minden esetben magukban hordozzák a földtani kockázatot, amely a felszín alatti tér bizonytalan ismeretébôl adódik. A földtani kockázat szakmailag megalapozott kutatási tevékenységgel csökkenthetô, melynek elengedhetetlen része a vizsgált területre vonatkozó archív geológiai és geofizikai adatok beszerzése, értékelése, szükség szerinti újraértelmezése, majd a feladat megoldását elősegító új mérések tervezése és kivitelezése. Az alkalmazott geofizikai kutatás egyik alappillére a szeizmikus kutatómódszer, mely hazánkban hosszú múltra tekint vissza a földtani alapkutatásban és a mélyföldtani szerkezetkutatásban (PoLCZ 2003, Bороку \& PolCz 2016), illetve rutinszerúen alkalmazzák a szénhidrogéniparban is. A szeizmika azonban még indokolatlanul kevés szerepet kap a változatos célú és léptékú földtani feladatok megválaszolásában, pedig a segítségével kialakított földtani modell jelentős mértékben csökkentheti egy - bármilyen célból - tervezett fúrás kockázatát.

Az 1950-es évektől Magyarországon is gyors ütemben fejlődő szeizmikus kutatás eredményeként az ország geofizikailag megfelelően megkutatott. Mára az eddig lemért $6699 \mathrm{db}$ 2D szelvény és $98 \mathrm{db}$ 3D adattömb közül $4786 \mathrm{db}$ 2D szelvény, valamint az összes 3D adatrendszer digitálisan is elérhetố az MBFSZ geofizikai adatbázisában. Mindez a szeizmikus ismeretanyag hozzájárult ahhoz, hogy kialakuljon egy általánosan elfogadott regionális léptékú földtani-geodinamikai modell, illetve fejlődéstörténeti keret a Kárpát-medence térségére, mely bárminemú földtani kutatáshoz jó alapot biztosít. Ezzel együtt a szeizmikus kutatási igények is átalakultak, a hangsúly áttevődött a helyi viszonyokat tisztázó, részletező mérésekre. A kutatási célok sokszínúségéből, illetve a lokális földtani és helyszíni adottságokból fakadóan minden egyes mérés egyedi kihívást jelent. Ezek optimális megoldásához a Magyar Bányászati és Földtani Szolgálat a kutatóintézeti gyakorlat szellemiségében, de az alkalmazott kutatás keretein belül - az elérendő földtani célt szem elótt tartva dolgoz ki mérési terveket és feldolgozási metodikákat, melyek gyakran kísérleti mérésekkel is párosulnak.

Jelen tanulmányban három különböző léptékú és célú szeizmikus méréssel megtámogatott kutatást (1. ábra) ismertetünk az MBFSZ közelmúltjából, mely minden esetben új, részletesebb földtani adatokat szolgáltatva jelentôsen hozzájárult a rendelkezésre álló földtani modell pontosításához. Felvázoljuk a több évtizedes múltra visszatekintő nyugat-mecseki szerkezetkutatás legújabb szeizmikus eredményeit. Az alkalmazott témakörből egy geotermikus célú kutatás módszertanát és eredményeit mutatjuk be a győri geotermikus projekt példáján, majd a nagyfelbontású szeizmikus mérések felhasználási lehetőségére hozunk példát a borsodi szénkutatásban.

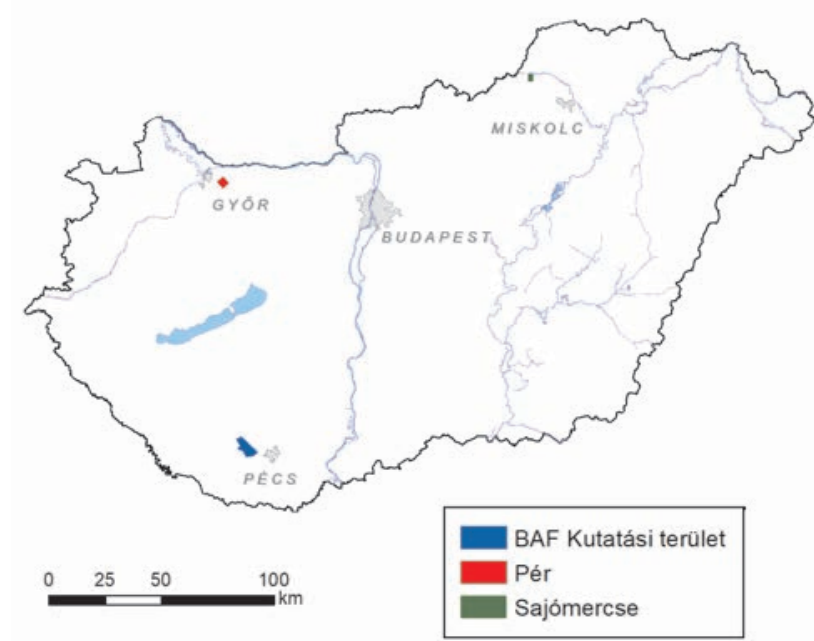

1. ábra. A kutatási területek elhelyezkedése: Nyugat-Mecsek, győri geotermikus projekt (Pér) és Sajómercse

Figure 1. Locations of the studied areas: West Mecsek, Györ Geothermal Project (Pér) and Sajómercse 


\section{Az MBFSZ szeizmikus kutatási múltja és jelenlegi technikai háttere}

A szénhidrogénipar növekvő igényeihez alkalmazkodva a szeizmikus kutatás fellegvára az 1900-as évek közepétől kezdve az Eötvös Loránd Geofizikai Intézet (ELGI) volt. 1951-ben megjelent az első hazai gyártmányú 24 csatornás szeizmikus berendezés (SZM 26/53), majd ezt követte a mágneses jelrögzítésû szeizmikus felvevô berendezés (SZM-24+6) fejlesztése, a személyi számítógépekre alapozott terepi szeizmikus előfeldolgozó-rendszerek fejlesztése az 1980-as évektől, majd az ESS mérnökgeofizikai múszercsalád sikere, illetve az ezek nyomán kibontakozó nemzetközi kutatási expedíciók többek között Kínában, Mongóliában, Kubában, később Görögországban (BODOKY \& Polcz 2016). Az ezredforduló táján a szeizmikus fejlesztések iránya megváltozott, az autonóm szeizmikus eszközök építése és alkalmazása került előtérbe. Ezeket Magyarországon és több nemzetközi nagyszerkezeti kutatásban is sikeresen használták (BoDOKY \& Polcz 2016).

Az 1990-es évek társadalmi, gazdasági átalakulásának következtében a szeizmikus kutatás is jelentősen visszaesett Magyarországon. A 2000-es évektôl a megváltozott igényekhez alkalmazkodva kisebb volumenú, ám szerteágazó szeizmikus mérések történtek a MÁELGI-ben, majd utódintézményeiben (I. táblázat).

2015 óta az MBFSZ elsôsorban Sercel 428 Lite adatgyưjtővel végez méréseket, mely lehetővé teszi 1000 csatorna egyidejű mérését $1 \mathrm{~ms}$ mintavételi sûrûséggel. Ez az általunk megcélzott léptékben kiváló idő és térbeli felbontást biztosít. A kutatási célzóna függvényében jelforrásként elsősorban a Failing Birdwagen hordozóra szerelt IVI Mark IV. Y-2400 (21 t) típusú szeizmikus vibrátorok kerülnek alkalmazásra, melyet szükség esetén robbantásos jelforrás egészít ki.

I. táblázat. Nagyobb szeizmikus mérési kampányok a 2000-es évekből Table I. Superior seismic measurement campaigns from the 2000s

\begin{tabular}{llc} 
Földtani cél & Terület & Év \\
\hline Szerkezetkutatás & Bátaapáti & 2002 \\
& Nyírség & 2003 \\
& Nyugat-Mecsek & 2004,2018 \\
\hline Geotermikus kutatás & Iklódbördöce & 2007 \\
& Baja & 2008 \\
& Györ & $2013,2014,2017$ \\
\hline Szénkutatás & Mecseknádasd & 2013 \\
& Sajómercse & 2019 \\
\hline Zagytározók gátvizsgálata & Bokod & $2011-2019$ \\
& Almásfüzitö & 2014 \\
\hline Passzív szeizmikus monitorozás & Pusztaszer & 2006 \\
& Nyugat-Mecsek & $2004-2015$ \\
& Berettyóújfalu & 2012
\end{tabular}

A reflexiós adatok feldolgozása ProMAX (Halliburton/Landmark Corp.) és AVO (Hampson-Russell Software Services Ltd.) programcsomagok segítségével történt, a szelvények értelmezése pedig Landmark (Halliburton/ Landmark Corp.), valamint SMT ${ }^{\mathrm{TM}}$ Kingdom szoftveres környezetben. Az integrált földtani-geofizikai értelmezés eléréséhez az MBFSZ egyéb geofizikai (gravitációs, mágneses, geoelektromos, karotázs) adatbázisai, továbbá térképi és fúrási adatbázisai biztosítanak hathatós segítséget.

\section{Nyugat-Mecsek — Szerkezetkutatás}

\section{Geológiai környezet és földtani kockázat}

A Bodai Agyagkő Formáció (BAF) kutatásának leg utóbbi, 2013-2018 között zajló szakaszában az MBFSZ 2017ben reflexiós szeizmikus kutatást végzett a Mecsekérc Zrt. megbízásából a potenciális befogadó képződmény elterjedési területén. A Nyugat-Mecsek területén tervezett nagy aktivitású radioaktívhulladék-lerakó létesítésének feltétele, hogy a megcélzott földtani közeg (BAF) kiterjedése, vastagsága, térbeli pozíciója a következő 240-300 ezer év során megfeleljen a tervezett paramétereknek.

A két, összesen 30 km hosszúságú új szelvény a NyugatMecsek nyugati részén, a Bakócai-vetőzóna és a Mecsekaljazóna között, a Horváthertelend-Helesfa-Szentlőrinc-Okorvölgy települések által határolt térrészen húzódik (2. ábra). A területtôl keletre az utóbbi évtizedben zajló felszíni földtani térképezésnek köszönhetően jelentős földtani információ áll rendelkezésre (KonRÁD et al. 2016, MAJOROS \& MENYHEI 2017, SEBE et al. 2017). Mindkét — tektonikusan érintkező fő szerkezeti egység, a Kővágószőlősi-egység (vagy Központi-antiklinális) és a Goricai-egység felépítésében a változó összetételú kristályos aljzatra települő transzgressziós permotriász rétegsor, valamint neogén üledékek vesznek részt. A kristályos aljzatot ért deformációról kevés ismeret áll rendelkezésre, míg a permotriász rétegsort elsôsorban kréta és miocén korú szerkezeti mozgások deformálták (Hetvehely-Magyarszék-vetôzóna, Boda-Büdöskúti-vetőzóna, Bükkösdivető, Mecsekalja-zóna, 2. ábra, KonRÁD et al. 2016, HoRVÁTH et al. 2018), azonban ezek komplex genetikája, egymáshoz képesti viszonya nem minden esetben tisztázott.

A 2017-es szeizmikus kutatás elsődleges célja tehát a Nyugat-Mecsek szerkezeti egységeinek áttekintése, az azokat tagoló főbb szerkezeti elemek nyomvonalainak és tektonikai aktivitásának vizsgálata, illetve pontosítása volt a többnyire neogén üledékekkel fedett nyugati peremzónában. További célként fogalmazódott meg a perm rétegsor lehetőség szerinti tagolása, a BAF vertikális elterjedésének vizsgálata a kevésbé kutatott Goricai-egységben. A feladat a részét képezte a hazai nagy aktivitású radioaktív hulladékok végleges elhelyezését biztosító mélységi geológiai tároló telephelyének helyszínminősítéséhez, továbbá a következő kutatási fázis szúkebb célterületének kijelöléséhez szükséges információgyújtésnek és adatszolgáltatásnak (TUNGLI \& MolnÁr 2018). 


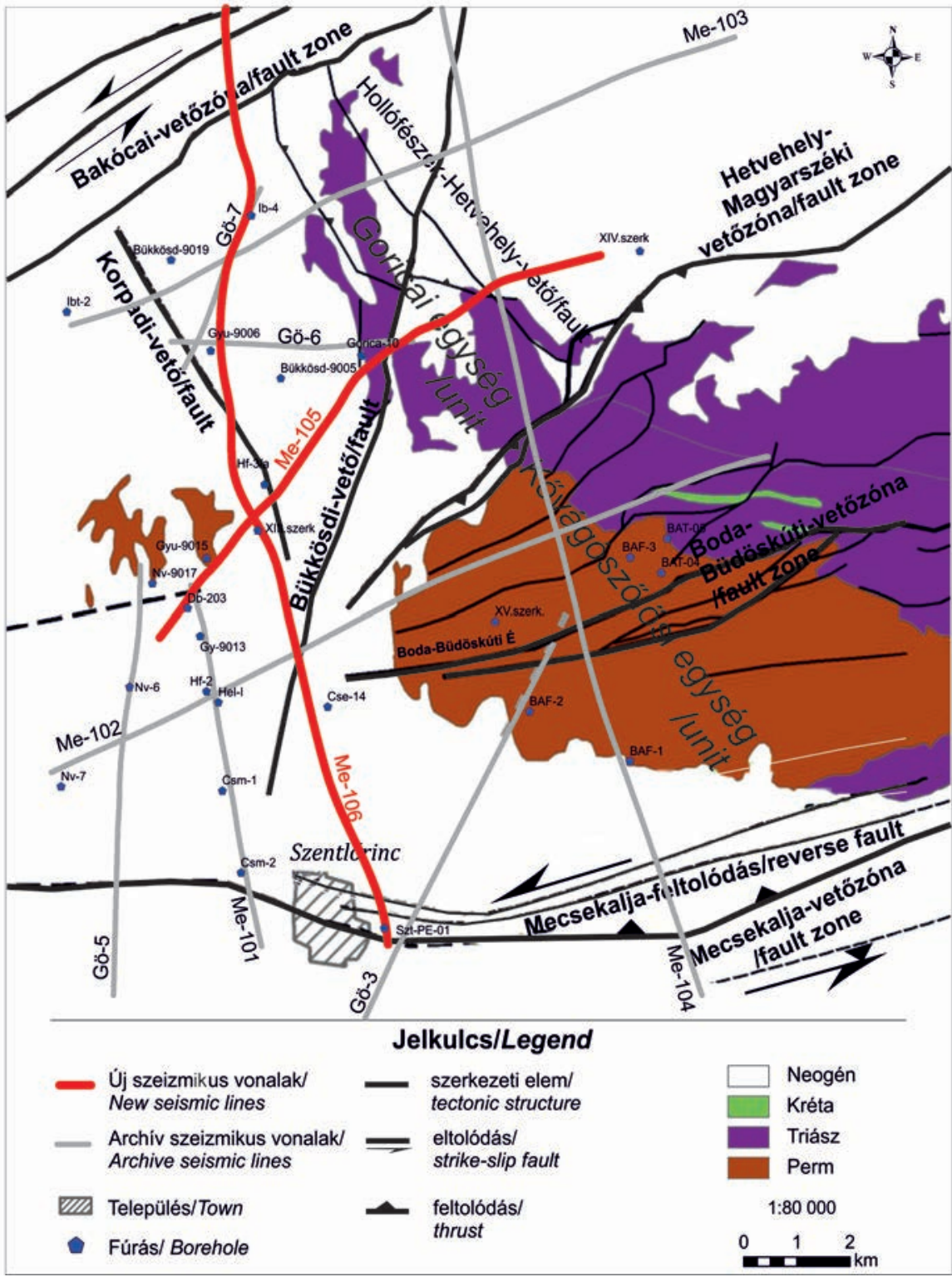

2. ábra. A Nyugat-Mecsek főbb szerkezeti elemei (KonRÁD et al. 2016, HoRVÁTH et al. 2018) a 2017-ben mért reflexiós szeizmikus kutatás nyomvonalának (Me-105 és Me-106), az archív szeizmikus szelvények és az értelmezéshez felhasznált fúrások feltüntetésével

Figure 2. The main tectonic elements of the West Mecsek (KONRÁD et al. 2016, HORVÁTH et al. 2018) also indicating the location of the reflection seismic profiles measured in 2017 (Me-105 and Me-106), the archive seismic lines and wells
$8-96 \mathrm{~Hz}$ volt mindkét vonal mentén.

A szeizmikus adatok feldolgozása két egymásra épülő lépésben történt. A hagyományos reflexiós feldolgozási folyamat végeredményeként elóállt „modellszelvény" bemenetként szolgált a második, Common Reflection Surface (CRS, közös reflexiós felület) szerinti feldolgozás végrehajtásához (JÄGER et al. 2001). A CRS szerinti öszszegzést az 1990-es évek végén olyan bonyolult földtani szerkezetek szeizmikus leképezésére dolgozták ki, amelyekrôl a hagyományos összegzési eljárás természeténél fogva nem adhat pontos képet. A gyưrt és meredek dőlésú felületekről kapott reflexiók ugyanis nem egyedi pontokról, hanem elemi felületekrốl verôdnek viszsza (YILMAZ 1999). Az elózetesen készített „modellszelvény” lehetőséget ad a dőlések becslésére, az újszerú összegzési algoritmus pedig a dőlésfüggő kilépési korrekciók számítására, az elemi felületek időben változó sugarának megadására és az adatok ezek szerinti összegzésére. A CRS feldolgozási folyamat gyakorlatilag az előfeldolgozott adatok összegzését jelenti a dőlések és az apertúrák figyelembevételével. Az eredmények meggyőzően mutatják a technika alkalmazásának jel/zaj arány növelő hatását (TAKÁCS 2018, TAKÁCS \& CSERKÉSZNAGY 2018).

\section{Alkalmazott módszer}

A szeizmikus szerkezetkutatás tektonikailag erősen deformált, morfológiailag tagolt zónában történt. Az előzetes földtani ismeretek alapján a mérések megcélzott mélységtartománya 500-2000 méter volt. A nehéz terepviszonyok miatt a mérést csak görbült nyomvonalak mentén lehetett kivitelezni, de még így is jelentôs topográfiai szintkülönbséget $(\mathrm{kb} .150 \mathrm{~m})$ kellett áthidalni, mely elsősorban a feldolgozás során jelentett szakmai kihívást. A terepi körülmények, továbbá természetvédelmi okok miatt a túlnyomóan vibroszeiz jelgerjesztés mellett szakaszonként robbantásos jelforrásokat is használtunk. Az alkalmazott geofonköz és a forrástávolság 20-20 m, a névleges fedésszám 200, a sweep (változó frekvenciájú vibrátoros forrásjel) frekvencia pedig

\section{Eredmények-Me-105 és Me-106 szelvény és értelmezésük}

A fenti eljárással elóállított 18,5 km hosszúságú Me-106 és 11,8 km hosszúságú Me-105 vonalak értelmezhetősége a megcélzott vizsgálati tartományban jónak bizonyult: a szerkezeti elemek felismerhetők, az eltérő szeizmikus jellegú blokkok biztonsággal azonosíthatók, a szeizmofáciesek többnyire jól követhetốk. A szelvények értelmezésénél a korábbi Me-101-104, illetve Gö-3,-5,-6 (2. ábra) szelvényeket is részben újraértékeltük.

Az É-D-i lefutású, a Nyugat-Mecsek fő szerkezeti irányaira közel merôleges Me-106 szelvény mentén viszonylag jól elkülönül a Nyugat-Mecsek két fő szerkezeti egysége, a Kővágószőlősi-egység és a Goricai-egység, melyek 
közt egy szélesebb vetőzóna jelöli ki a Hetvehely-Magyarszék-zóna feltételezhetô nyugati folytatását (3. ábra). A vetőzóna mentén a permi képződményeket elsősorban normálvetős elmozdulás érintette, míg a miocén elmozdulás tekintetében a szelvény nem nyújt számottevő új információt. KonRÁD et al. (2016) középső-miocén korú kompressziót feltételez, de az öv északkeleti részén kora-pannóniai transztenziót is dokumentáltak (KoNRÁD \& SEBE 2010).

A Hetvehely-Magyarszék-zónától északra elhelyezkedő Goricai-egységen belül elkülöníthető a Goricai kristályos blokk, illetve a Goricai-pikkely (cf. MAJOROS \& MENYHEI 2017). Ez utóbbiban a kristályos aljzat és a felette megjelenő permo-mezozoos üledékes sorozat egy északkeleties dőlésú lapos sík mentén érintkezik (3. és 4. ábra), mely MAJOROS \& MENYHEI (2017) értelmezésében egy lapos szögú rátolódás, mely feltételezhetóen a mezozoikumban múködött. A szelvényrész szeizmikus értelmezését az Ibafa-4 fúrás rétegsora és a benne elvégzett VSP (Vertical Seismic Profiling Vertikális Szeizmikus Szelvényezés, GöNZ \& RÁDLER 1985) mérés eredménye segíti: a legnagyobb amplitúdóval jelentkező szeizmikus jelek a triász Jakabhegyi Formáción belülről érkeztek. A Bodai Agyagkő Formáció felső határát egy közepes erôsségú negatív jel jelöli ki. A fúrás nem fúrta át a BAF képződményeit, és a szeizmikus jellegek alapján sem határozható meg a képződmény alsó határa, így maximális vastagságára a fentebb említett lapos dőlésú szerkezeti elem mélysége adhat egy elvi közelítést. Így a BAF vastagsága maximálisan 7-800 m-re becsülhető ezen a részen. Az Ib-4 fúrás szerkezeti értelmezése szerint a Kővágószőlősi és Bodai Agyagkő Formáció tektonikusan érintkezik, a BAF felsô, ismeretlen vastagságú része hiányzik, a fúrásban harántolt alsó szakasza pedig már a képződmény legalsó tagozatába sorolható (SÁMSON et al. 2017). Ez azt mutatja, hogy a BAF tényleges vastagsága ennél jóval kisebb lehet, mindössze 3-400 m, alatta a Cserdi Formáció is megjelenhet a kristályos aljzatra települve.

A szerkezeti egységet északról határoló törészóna a Bakócai-vetôzónának feleltethető meg, mely KonRÁD \& SEBE (2010) értelmezésében feltolódásos és oldalelmozdulásos zóna, melyet a Me-106 szelvény is alátámaszt. A Goricaipikkely délnyugati oldalát meredek dôlésú feltolódások jelölik ki (Tz-4), amelyek mentén a triász összlet a prepannóniai miocén üledékekre tolódott. E szerkezeti elemek értelmezhetők a mezozoos szerkezeti elem (MAJOROS \& MENYHEI 2017) felújulásaként is (3. és 4. ábra).

A szelvény a középső részén — a Goricai kristályos blokkban - egy kaotikus szeizmikus fáciessel jellemezhető, erôsen tektonizált zónát mutat. A fúrások alapján a kristályos aljzat kiemelt helyzetben van, azon idős perm rétegek települnek, majd nagy vastagságú (akár 400 m) miocén üledékek következnek. A szelvény 8,5-9 km-énél egy meredek dőlésekkel jellemzett, feltehetôleg oldalelmozdulásos zóna ismerhetô fel, amely vélhetôleg a Korpádi-vetőnek feleltethető meg (3. ábra).

A Kővágószőlősi-egységben a paleozoos kristályos aljzat a mélybe süllyed, a rátelepülő idősebb permi üledékek pedig feltehetően kivastagodnak. Fúrás (Cse-14) csak a fel- ső 300 m-t tárja fel, ami a miocén üledékek alatt a Cserdi Formációt érte el. A kivastagodó összletben egy jellegzetes szeizmikus vezérszint jelenik meg, ami a Gyuurúfúi Riolit megjelenésével hozható összefüggésbe. Az egységet délről egy markáns déli vergenciájú feltolódási zóna határolja, ami mentén a perm képződmények triász karbonátokra, illetve miocén üledékekre tolódnak (Tz-2, Mecsekalja-feltolódás). A szelvény mentén értelmezett feltolódást a Szt-PE-01 fúrásban is azonosították. A szelvény 16 . km-énél a pannóniai képződményekbe is felharapódzó feltolódások észlelhetők. A Mecsekalja-feltolódás jól korrelálható a környező szelvényeken (Me-101,-104, Gö-5), melyek egy viszonylag lapos dőlésú (10-30) szerkezeti elemet (FANCSIK et al. 2010, MAJoros \& MenyHei 2017; Konrád in SEbe et al. 2017, CSERKÉSZ-NAGY et al. 2018) körvonalaznak a Mecsekaljazóna nyugati, fedett részén, szemben a keletebbi területeken, feltárásban is leírt 50-60-os dőlésû feltolódással. Ez az összetett szerkezeti zóna több fázisú, bonyolult tektonikájával magyarázható.

Az ÉK-DNy irányú Me-105 szelvény (4. ábra A) a Goricai-egység szerkezeti áttekintését szolgálja. A szelvény 3-6 km közti szakaszán megjelenô kb. 0,4 s-ig mélyülő „árkos szerkezet” képezi a Goricai-pikkely és Goricai kristályos blokk közti határzónát. Az árok keleti peremén a Goricai-magaslat permo-triász rétegsora a felszínre bukkan, illetve fúrások sora (pl. Gorica-10, Ib-4) is feltárja azt. A Me-106 szelvényen (3. ábra) is értelmezett lapos szögú sík, amely mentén a Goricai-pikkely permo-mezozoos üledékes összlete érintkezik a paleozoos kristályos képződményekkel, a Me-105 szelvényen is azonosítható. A kristályos aljzat mélyebb zónáiban több hasonló, északias dőlésú lapos feltételezhetően tektonikai — sík ismerhető fel. A szelvény keleti részén az erős töredezettség miatt a reflexiók követése nehézkes, a XIV. szerkezetkutató fúrás tanúsága szerint a permo-triász rétegsor kelet felé a miocén üledékek alá bukik, és erôteljesen kivastagodik.

Az ároktól nyugatra elhelyezkedő fúrások miocén üledékek alatt változatos alsó-perm rétegsort, illetve a Mórágyi Komplexum kristályos kőzeteit tárták fel. A 0,2-0,3 s közt megjelenő nagy amplitúdójú reflexiókötegek a fúrások alapján a Korpádi Homokkő Formáció és a Gyúrúfưi Riolit Formáció képződményeiként értelmezhetők, melyek hasonlóan jó folytonosságú, közepes/nagy amplitúdójú jelekként mutatkoznak a Me-106 szelvény Kővágószőlősi-egységében is.

A szelvény legérdekesebb része a Goricai-pikkely és a Goricai kristályos blokk között húzódó árok. Mélyebb részén jó folytonosságú, vízszinteshez közeli települést mutató, közepes-erós reflexiók jelentkeznek, amelyek a gravitációs (KISS 2003) és szeizmikus sebességtomográfiás mérések (KovÁcs 2005) eredményeiben kis súrûségű, kis sebességú üledékként jelennek meg az ÉNy-DK-i csapású árok területén; ez alapján miocén üledékes kitöltésként értelmezhetők. Az árkot feltáró egyetlen fúrás, a szelvénytől északra mélyült Bükkösd-9005 azonban már viszonylag kis mélységben permi képződményeket jelez: 297 m mélységben BAF-ot tárt fel. E látszólagos ellentmondás a jelenlegi szelvények segítségével 


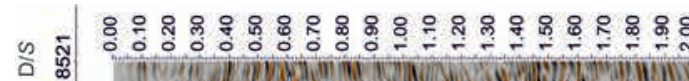

各:

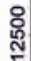

:

员 :

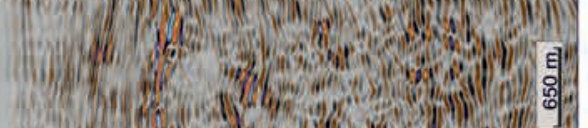

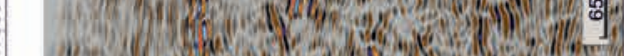

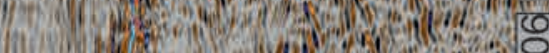

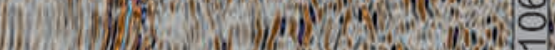

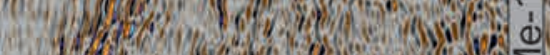

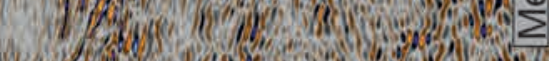

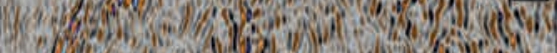

:

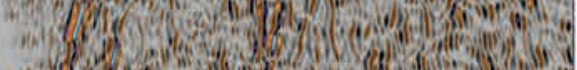
.

.

3e A

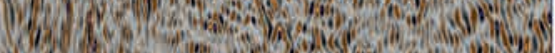

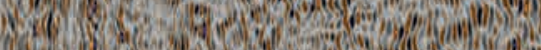

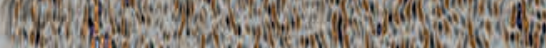

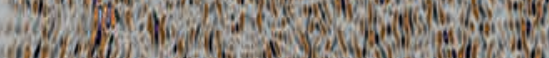

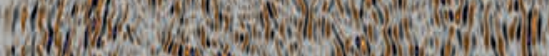

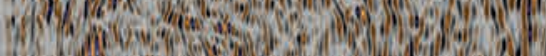
IC

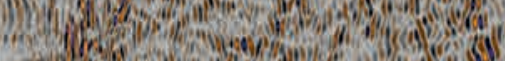

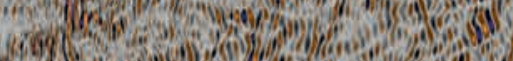
3.40 deven

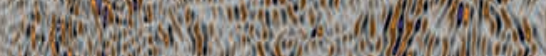

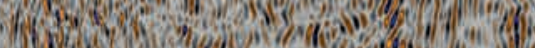

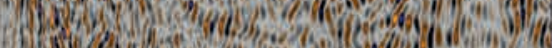

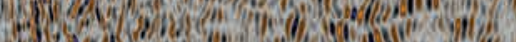

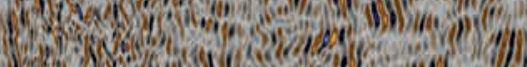

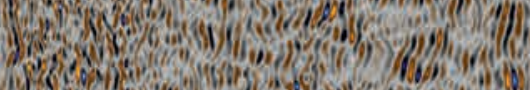
geres

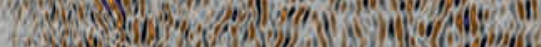

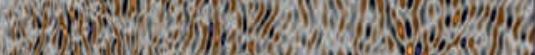
980

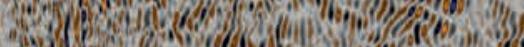
ina

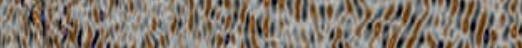

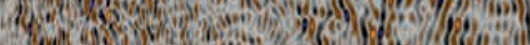

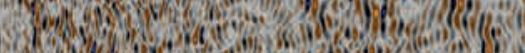

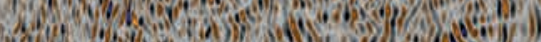

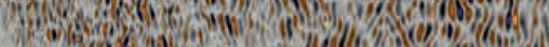

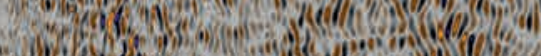

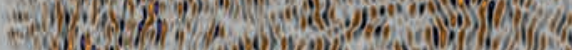

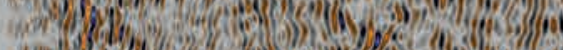

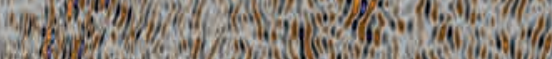

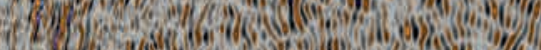

Wo ME2 ReW

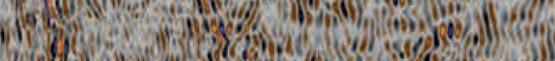

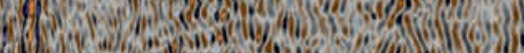

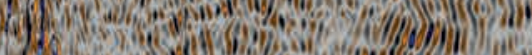
Cok

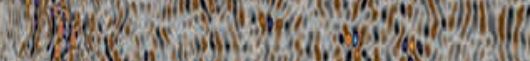
: 1)

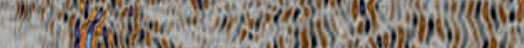

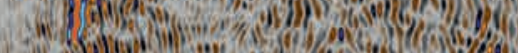

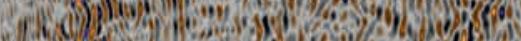
Wadpe

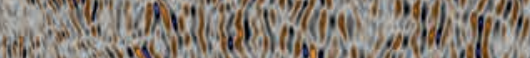

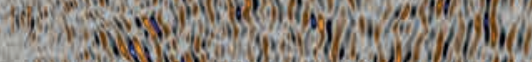

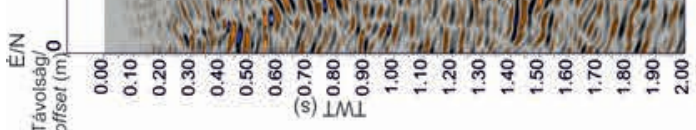

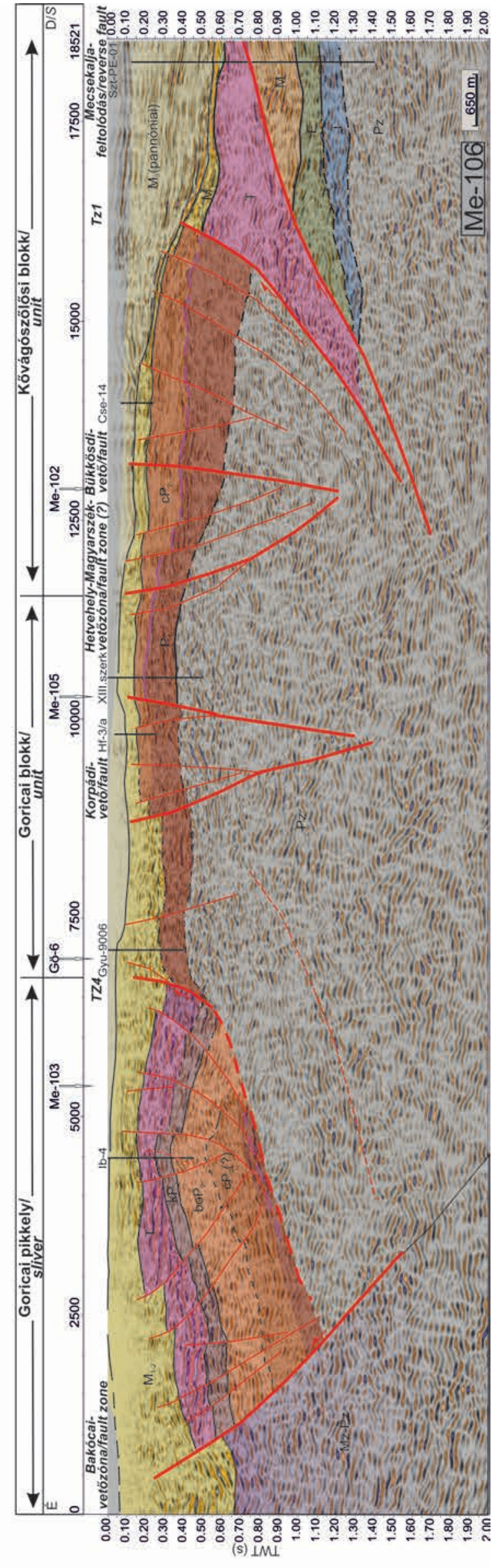

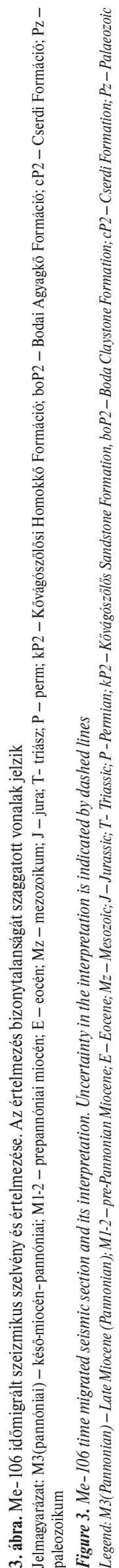




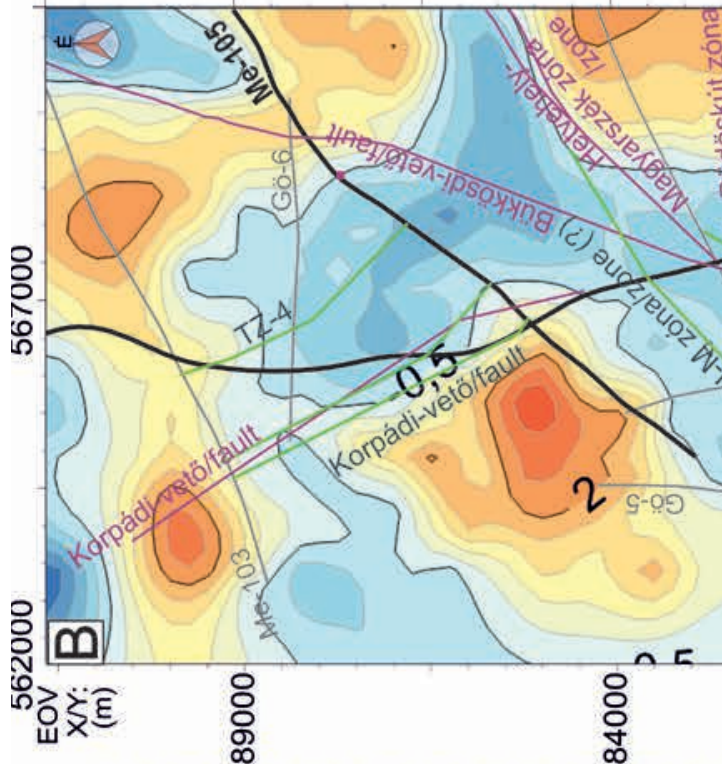

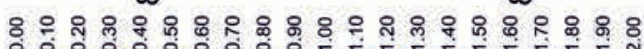

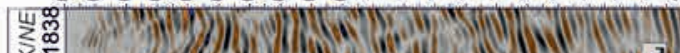
눈

cair

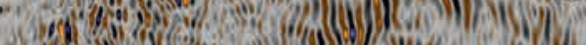

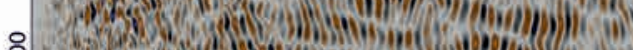
-

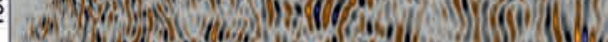

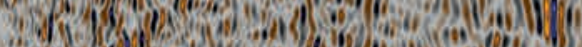

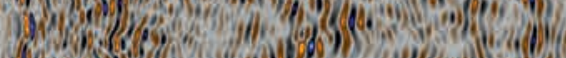

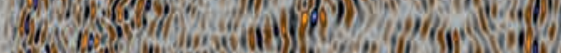

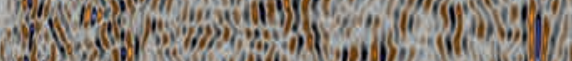

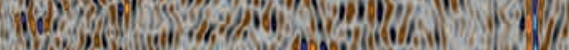
sim. (3) s)

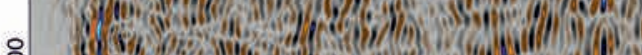

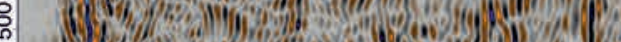

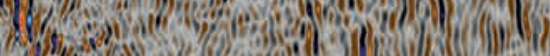

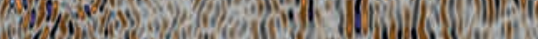

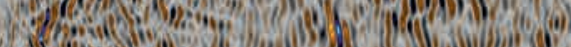

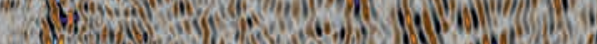

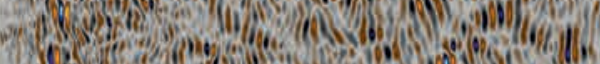
3o (a)

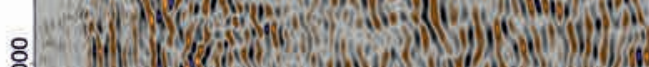
:

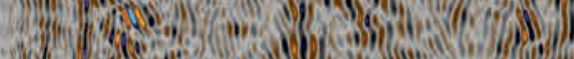
wot (2)

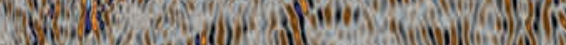

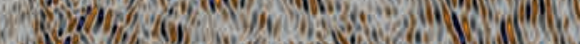

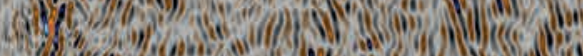
120

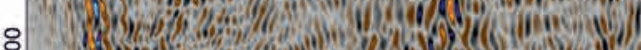
कू

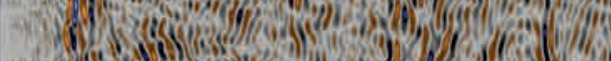

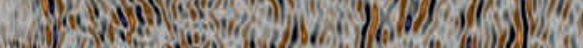

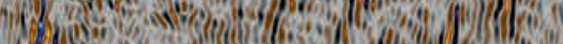
agewa.t. Wa

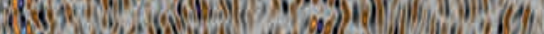
空

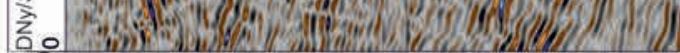

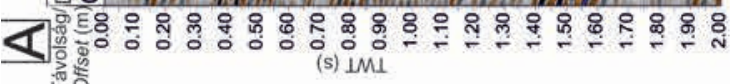

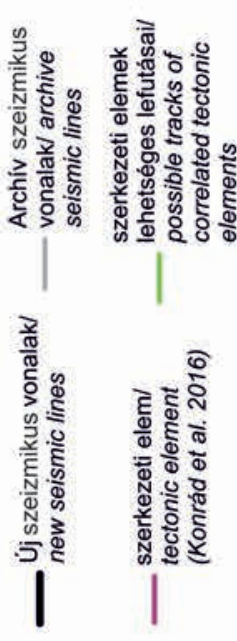

융

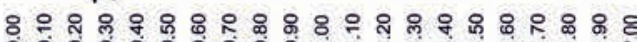

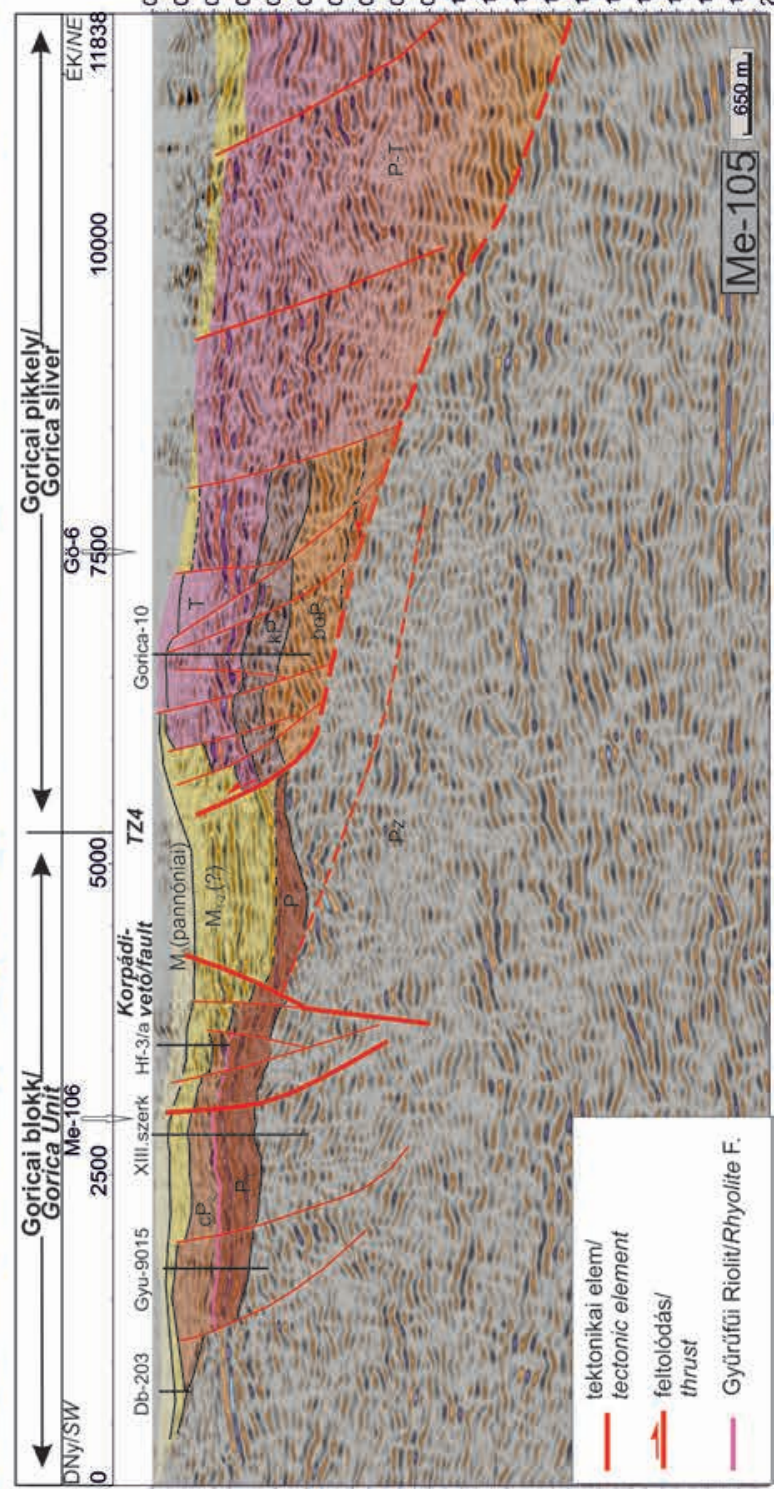

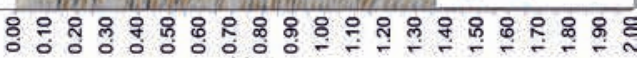
(s) $1 M \perp$

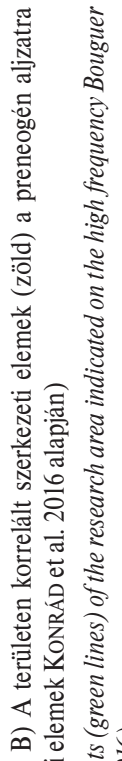

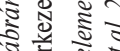
r.

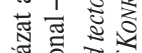

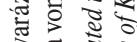

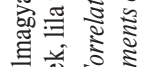

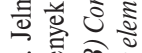
离离的

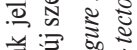

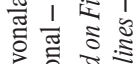

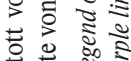

总芯

岕导芯

要空芯 赔

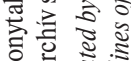

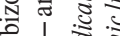
出

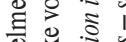
过: 离

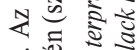
幽 焉 $\Xi$

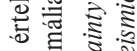
\%) $\frac{2}{b_{0}}=$ की :

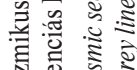

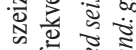
뉸 光 응 8 은 dis $\sum^{2}$ 号 $\varangle \frac{\pi}{4}$ 通总 灾 芯 
nem oldható fel megnyugtatóan. A 4. ábra A részén bemutatott, az egyéb geofizikai mérésekre is támaszkodó értelmezés szerint az árok kinyílását megelőzóen nagymértékú erózió történhetett, ami a BAF képződményeinek vastagságát jelentősen csökkentheti. Továbbá a miocén szerkezeti mozgások jelentôségét is hangsúlyozza a Tz-4 zóna környezetében (CSERKÉSZ-NAGY et al. 2018). Ezzel összhangban az árok nyugati peremén is mutatkozik egy, az alsó-középső-miocén (esetleg pannóniai) üledékeket is elvető virágszerkezet, amely a Me-106 szelvényen felismert vetőzónával (Korpádivető) korrelálható, ami jelen értelmezésben a BAF nyugati elterjedési határát is jelentheti. A jelenlegi ismereteink alapján nem zárható ki azonban az árkos szerkezet perm korú kitöltése sem.

Összegzésként elmondható, hogy a két új szelvény földtani-szerkezeti értelmezése alapján pontosíthatók a régóta ismert szerkezeti elemek nyomvonalai (4. ábra, $B$ ): a Mecsekalja-feltolódás némileg északabbra húzódhat több jól azonosítható feltolódással kísérve, a Hetvehely-Magyarszék-vetôzóna kiterjeszthetô nyugat felé, a Korpádi-vetô pedig több vetőből álló zónaként értelmezhetô. Az értelmezés hangsúlyozza a kora-középsố-miocén kompressziós események jelentőségét, különösen a Goricai-egység területén. Az új szelvények megerósítik azt az elképzelést, hogy a BAF mind vastagságát, mind elterjedését tekintve jóval változékonyabb kifejlődésú a Goricai-egységben, mint a Kővágószőlősiegységben, ahol a központi részen a vastagsága az $1000 \mathrm{~m}$-t is elérheti. Így a további részletesebb kutatásra az az egység javasolt.

\section{Györi geotermikus projekt}

\section{Geológiai környezet és földtani kockázat}

A Kisalföldön, Gyơrtốl keletre, Pér és Bőny települések környezetében ( 1 . ábra) végzett geotermikus célú szeizmikus vizsgálatainkat 2012-ben kezdtük el a PannErgy Nyrt. megbízásából. A Dunántúli-középhegységi-egység szinklinális szerkezetének ÉNy-i szárnyán elhelyezkedő kutatási területen a hőtermelés számára elegendő mennyiségú, $100^{\circ} \mathrm{C}$ feletti kifolyóvíz-hőmérsékletú termelés csak a karsztosodásra hajlamos karbonátos prekainozoos aljzatból várható. A változatos felépítésú, de túlnyomóan triász korú sekélytengeri és platformkarbonátokból (Iszkahegyi Mészkő, Megyehegyi Dolomit, Fódolomit Formáció), valamint medence üledékekből (Felsőörsi Mészkő, Buchensteini és Veszprémi Márga Formáció), ÉNy-on sziliciklasztos (Balatonfelvidéki Homokkő Formáció) és enyhén metamorf paleozoos képződményekből (Lovasi Agyagpala Formáció) összeálló medencealjzat -1500- -4500 mBf mélységek közt ÉNy felé lejt (5. ábra; HAAS et al. 2010). A prepannóniai miocén képződmények igen változatosak, azonban a neogén rétegsor nagy részét a pannóniai képző́dmények teszik ki.

A geotermikus kutak telepítése során a mélybeli hőmérséklet jól becsülhetô - az elvárt kifolyó vízhőmérséklet a helyi geotermikus gradiens alapján kb. 3000 m mélységből várható, azonban a vízhozam akár 100 m-es távolságon belül is nagyságrendi eltérést mutathat a kôzettani, fáciesbeli vagy tektonikai változékonyság miatt. Az elvárt legalább 90 1/s mennyiségú vízkivételt nyitott vetőzónából vagy törésrendszerből lehet remélni, így az aljzati tároló mélységének és heterogenitásának reflexiós szeizmikus módszerrel történő térképezése mellett kiemelt hangsúlyt kapott a szúkebb terület szerkezeti értelmezése is. Noha a karsztos aljzati felszín általában jó vízadó, az elvárt vízkivétel mértéke a korábbi bányászati és lyukgeofizikai tapasztalatok alapján a területen kétséges volt.

\section{Alkalmazott módszer}

A megfogalmazott geotermikus célokat szem előtt tartva a fokozatosság elvét követő, több éven át tartó szeizmikus kutatási programot hajtottunk végre: 15 db archív 2D szelvény újrafeldolgozása és értelmezése (1) után 6 db új hálózatkiegészítő, 2D reflexiós szelvény (Per-1-6) került lemérésre (2), melyek feldolgozása és értelmezése nyomán történt a Per-Pe-01 kút kijelölése és lefúrása (3). A kutatás következő fázisában kisméretú, részletező 3D mérés, illetve ennek adatfeldolgozása (4), majd az összes rendelkezésre álló adat együttes földtani értelmezése (5) nyomán történt meg a további termeló és visszatápláló kutak helyeinek kijelölése (Per-Pe-2, Bon-Pe-01, -02 kutak) (6).

A 2D vonal menti mérések esetén a geofonköz és a forrástávolság 30-30 m volt a megcélzott 2-3000 m mélységú medencealjzat megkutatására, a $3 \mathrm{db}$ vibrátorral gerjesztett jel frekvenciája pedig $8-96 \mathrm{~Hz}$ volt.

A 3D mérés során $8 \mathrm{db}$, egymástól 500 m-re húzódó nyomvonal mentén összesen $500 \mathrm{db}$ autonóm üzemú adatgyújtó egyidejúleg regisztrált 50 m-es közzel. A maximális offset az eltéró vonalhosszak miatt 3-5 km között volt. A 12 másodperc hosszúságú, $10-80 \mathrm{~Hz}$ frekvenciájú szeizmikus jeleket $2 \mathrm{db}$ nagy teljesítményú vibrátor gerjesztette 3 -szoros ismétléssel. A kábel nélküli mérőeszközökkel és a nem szabályos geometriájú - főleg a földutakra telepített forráspontok rendszerével megvalósított 3D mérés a zöldkultúrákat kíméló módon, gazdaságilag racionális keretek közt szolgáltatta a kutak megtervezéséhez szükséges lokális, részletezó szerkezeti ismereteket.

A rendelkezésre álló 3D szeizmikus adatok lehetôséget adtak további kísérleti módszertani vizsgálatokra a megvalósult termelő kutak alaphegységi környezetének kőzetfizikai minősítéséhez. Az Amplitude Versus Offset (AVO-) analízist a szénhidrogén-tartalmú porózus kőzetek elôrejelzésére már több mint két évtized óta sikeresen használják a hazai szénhidrogéniparban (TAKÁCS 1996, TAKÁCS et al. 2001, LÓRINCZ 2019). Az eljárás geotermikus kutatási célokra történő alkalmazásának lehetőségei azonban még napjainkban sem teljesen tisztázottak (CAMELI et al. 2000, AlEARDi \& MAZzotTI 2012), ebból kifolyólag ritkán alkalmazott vizsgálati módszer.

Az AVO-analízis módszertana (CHOPRA \& CASTAGNA 2014) a P- és S-hullámok porózus földtani képződményekben való terjedésének eltérésén alapszik, ugyanis ilyen kör- 


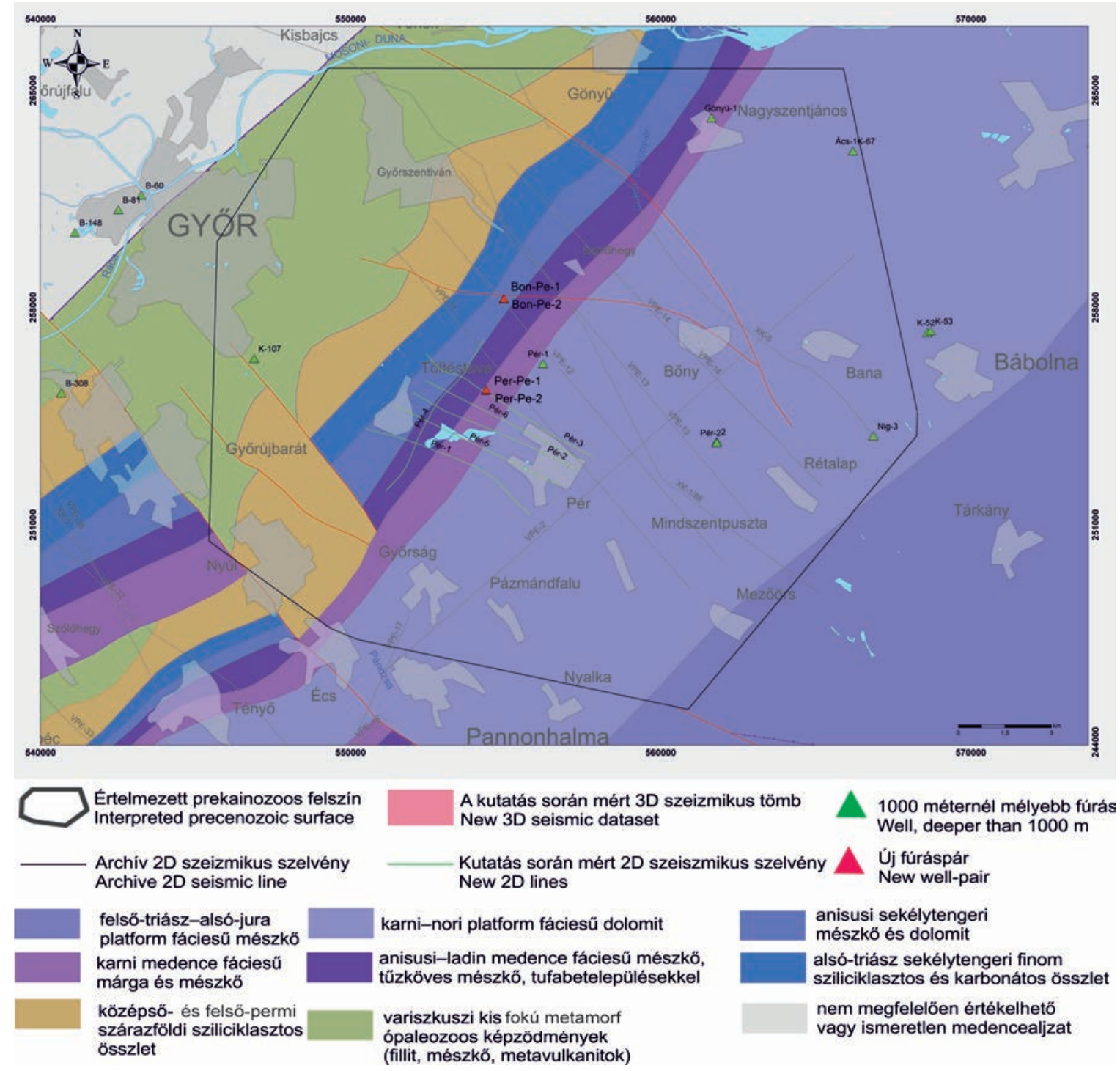

5. ábra. A kutatási terület helyszínrajza és prekainozoos medencealjzatának térképe HAAS et al. (2010) alapján

Figure 5. Location and pre-Cenozoic basement map (after HAAS et al. 2010) of the study area

nyezetben a Poisson-hányados lecsökken. Ez a kőzetfizikai sajátosság a reflexiós amplitúdók észlelési távolság (vagy beesési szög) függvényében való anomális növekedésében is megnyilvánul, ezért az összegzés előtti adatok növekvő AVO-válaszait keressük a szénhidrogén- és a geotermikus tárolók kutatása során is. Az eljárás elsôsorban gáztartalmú rétegek kimutatására alkalmazható, mivel ezek markáns AVO-anomáliákat okoznak. A folyadék halmazállapotú pórustartalom is eredményezhet anomáliát a reflexiós amplitúdó beesési szögtől való függésében, azonban ezek kevésbé markánsak, mint gáz (vagy gőz) jelenlétekor.

Az AVO-analízis végrehajtásához a terepi adatok amplitúdóhú előfeldolgozása szükséges, amely több tekintetben is eltér a földtani-szerkezeti értelmezéshez általában alkalmazott feldolgozási folyamattól. Egyrészt vissza kell állítani a szeizmikus csatornáknak a hullámterjedés és az észlelés következtében természetszerúleg torzult amplitúdóviszonyait, másrészt pedig kerülni kell azokat a múveleteket, amelyek megváltoztatják a csatornák közötti „,relatív ampli- túdókat". Másként fogalmazva, az AVO-analízis bemeneti adatainak — lehetőség szerint — csak a litológia és a porozitás változásaival kapcsolatos reflexiós amplitúdóváltozásokat szabad tükröznie. Ennek érdekében a 3D adatokon az AVO-inverzió elvégzése előtt speciális amplitúdóhú adatfeldolgozási folyamatot (MAzzotTI \& MirRi 1991, YILMAZ \& DOHERTY 2001) alkalmaztunk (II. táblázat).

\section{Az egyesített geológiai-geofizikai értelmezés eredményei}

A medencealjzat felszínének meghatározása 21 db szeizmikus szelvény és a 3D mérés metszeteinek értékelésével készült. A medencealjzat kijelöléséhez a Pér-1, Pér-2, Gönyú-1 és Nig-3 mélyfúrások (5. ábra) rétegsorait, lyukgeofizikai adatait és az utóbbi két fúrásban végzett szeizmikus sebességadatokat használtuk fel.

Az értelmezett prekainozoos tetôszint megbízhatóságát 
II. táblázat. Az AVO-analízis előtt alkalmazott amplitúdóhủ adatfeldolgozási folyamat legfontosabb lépései

Table II. The most important steps of the true amplitude data processing applied before the AVO analysis

Adatfeldolgozási lépés

A müvelet célja és eredménye

Valódi amplitúdó-helyreállítás

Felszin konzisztens amplitúdókorrekció és dekonvolúció

Összegzés elötti időmigráció

Idöben változó automatikus statikus korrekció
Korrigálja a hullámterjedéskor fizikai okok miatt fellépö amplitúdóveszteségeket (gömbi szóródás és energiaelnyelôdés).

Korrigálja a terepi körülmények változása miatt adódó amplitúdó- és jelalaktorzulásokat (forrás és észlelés oldali csatolások változása).

Összegzés elött eltávolitja a reflexiós beérkezéseket torzitódiffrakciókat, melyek a hirtelen földtani változásokról származnak.

Tovább javitja a reflexiók koherenciáját és ezzel az amplitúdók észlelési távolsággal való változásának meghatározását az összegzés elötti adatokon. tovább növelte a fiatalabb fedőképződmények települési diszkordanciája, illetve az idősebb feküképzódmény belsejében kijelölhetô rátolódási síkok szelvénymenti elmetsződési pontjainak meghatározása. A geológiai modellépítés részeként az erre alkalmas, jó minőségú szelvények mentén a szeizmikus anyag amplitúdó- és frekvenciasajátosságainak vizsgálatával sikerült korrelálni az egyes fúrásoknál azonosított aljzatbeli kôzeteket.

A mezozoos dolomitos aljzat intervallumsebessége $5200-6000$ m/s. A diszkordánsan rátelepüló neogén, medencekitöltő üledékekkel való határfelülete jellemzően nagy amplitúdójú, 20-30Hz frekvenciájú reflexióként azonosítható. A karbonátos aljzat belsejéből kisfrekvenciás, erôs reflexiójú jelek figyelhetôk meg a Pér-1 és Pér-2 fúrások által feltárt Fődolomitos szakaszokon. A Pér-1 fúrás több mint $400 \mathrm{~m}$ vastagságban harántolta a felső-triász összletet, ahol 2275-2310 m, 2320,5-2367,5 m, 2389-2642 és 2674-2695 m mélységintervallumokban nagyobb áteresztốképességú zónákról ír a kútkönyv. Ilyen vastag vízadó szerkezetek kevéssé ismertek a dolomitos összletekben, de jelenlétüket a karotázsgörbék is megerősítik.

A mezozoos márgák, sziliciklasztos képződmények hullámterjedési sebessége 4800-5400 m/s. A neogén medencekitöltố üledékek alatt — a kisebb impedanciakülönbség miatt — a márgás aljzat felszíne kis amplitúdóval és nagyobb (30$40 \mathrm{~Hz}$ ) frekvenciával jelentkezik, belsô szerkezete pedig kis amplitúdójú jelekkel üledékes jelleget mutat. A Gönyú-1 fúrás környezetében az azonosított szeizmikus fácies a Veszprémi Márga képződményeivel korrelál.

A neogén korú fedőüledékek — agyagok, márgák, homokkövek - 1800-3500 m/s hullámterjedési sebességekkel jellemezhetôk. Ezen üledékek hullámképe eltér a prekainozoos aljzat felszínéról érkező reflexióktól. A legmarkánsabb különbség a jelek koherenciájában (rendezettségében) nyilvánul meg. A nyugodt településú neogén korú üledékes összletre jellemző rendezettség leromlik a szerkezetileg erôsen igénybe vett, gyứrt, zúzott zónák mentén a reflexiók jelentős torzulása és a jelek szóródása miatt. Egyes pannóniai-posztpannóniai korú vetők mélybeli folytatásában - mélyen a medencealjzatban — az elmozdulások gyökérzónái is felismerhetőek.
Az értelmezés során három deformációs fázishoz tartozó szerkezeti elemek korrelációja történt meg (6. ábra). (1) A kréta közepén létrejött, ÉNy-i vergenciájú rátolódások ( $F 1$, F2), melyek a mezozoos szinklinális képződményeit egymásra tolták (TARI 1994, FODOR 2010). (2) Miocén korú szinrift normálvetők (N1-N8), melyek a Kisalföld alatti neogén üledékes medence extenziós felnyílásának következtében alakultak ki. (3) Pannóniai eltolódások (P1-P5). A szelvényeken a prekainozoos összlet tetôszintje az eltolódási zónák környezetében egyenetlen, töredezett képet mutat.

A pannóniai vetôrendszer menti elmozdulások a VPEszelvények és az újonnan mért adatok alapján nem egyértelmúek, és az elmozdulásuk jellege lokálisan változik. Egyaránt kimutathatók pozitív és negatív virágszerkezetek is, így a vető vízadó képességének megbecsülése csak nagy kockázattal tehetô meg. Noha a pannóniai korú vetôrendszer fiatalabb, kisebb eséllyel cementálódott és agyagosodott el, a hidrológiai szakvélemények alapján az idősebb, N jelú vetők lehetnek jó vízadók. Ezt igazolja, hogy a Per-Pe-1 fúrás esetében a megcsapolás egy több méter átmérójú nyitott vetőből történik. Az együttes értelmezés során kialakított geológiai modell alapján az $\mathrm{N}$ jelú, középső-miocén korú, a kisalföldi neogén medence extenziós felnyílásakor kialakult szinrift normálvetők mentén lehetett a legkisebb kockázattal telepíteni a termelő és a visszasajtoló kutakat. A kisméretú 3D mérés már ezen konkrét vetőzónák térbeli helyzetének pontos meghatározásához (7. ábra) készült a korábbiakban a szeizmikus fácies alapján kitérképezett megfelelő mélységú karbonátos tároló célterületén. A 6. ábrán bemutatott $2 \mathrm{D}$ szelvényen, ugyan a Per-Pe-1 fúrás által harántolt $\mathrm{N} 5$ jelú vetô lefutása és kinematikája nehezen meghatározható, de a célzott 3D tömbön jól követhetô, és egy jelentôsebb vetőrendszer tagjaként értelmezhetô (N5, N7 7. ábrán).

A kísérleti AVO-vizsgálatok során az előfeldolgozott terepi adatokból számos AVO-attribútum készült. A részletesebb elemzéshez az úgynevezett skálázott Poissonhányados változás attribútum bizonyult a legcélravezetőbbnek, mely arányait tekintve összefüggésben van a litológiával és a kőzetek porozitásával (CHOPRA \& 


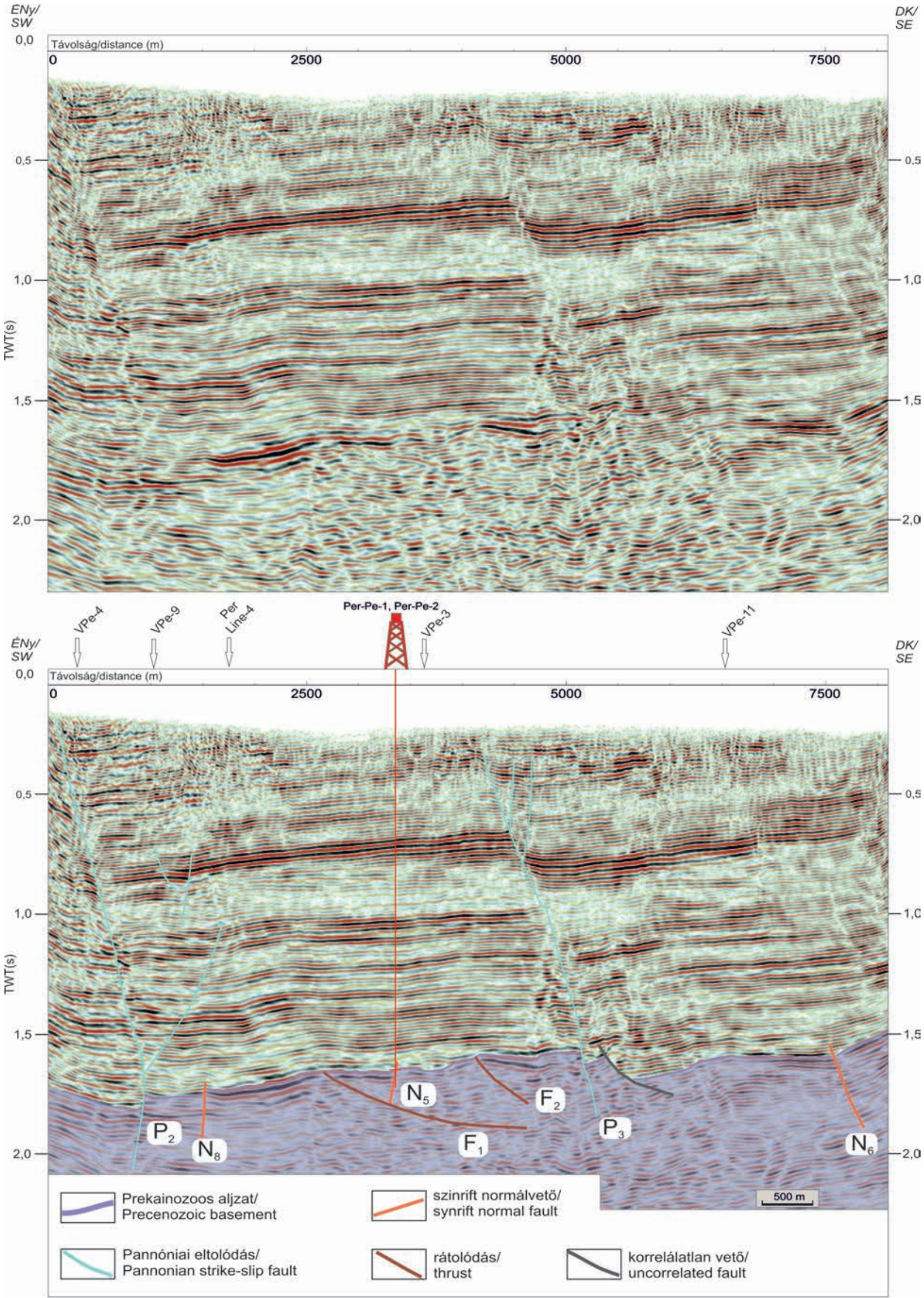

6. ábra. Per-3 értelmezett szeizmikus időszelvény a területen korrelált szerkezeti elemekkel

Figure 6. Per-3 interpreted time-migrated reflection seismic section with the correlated tectonic elements 


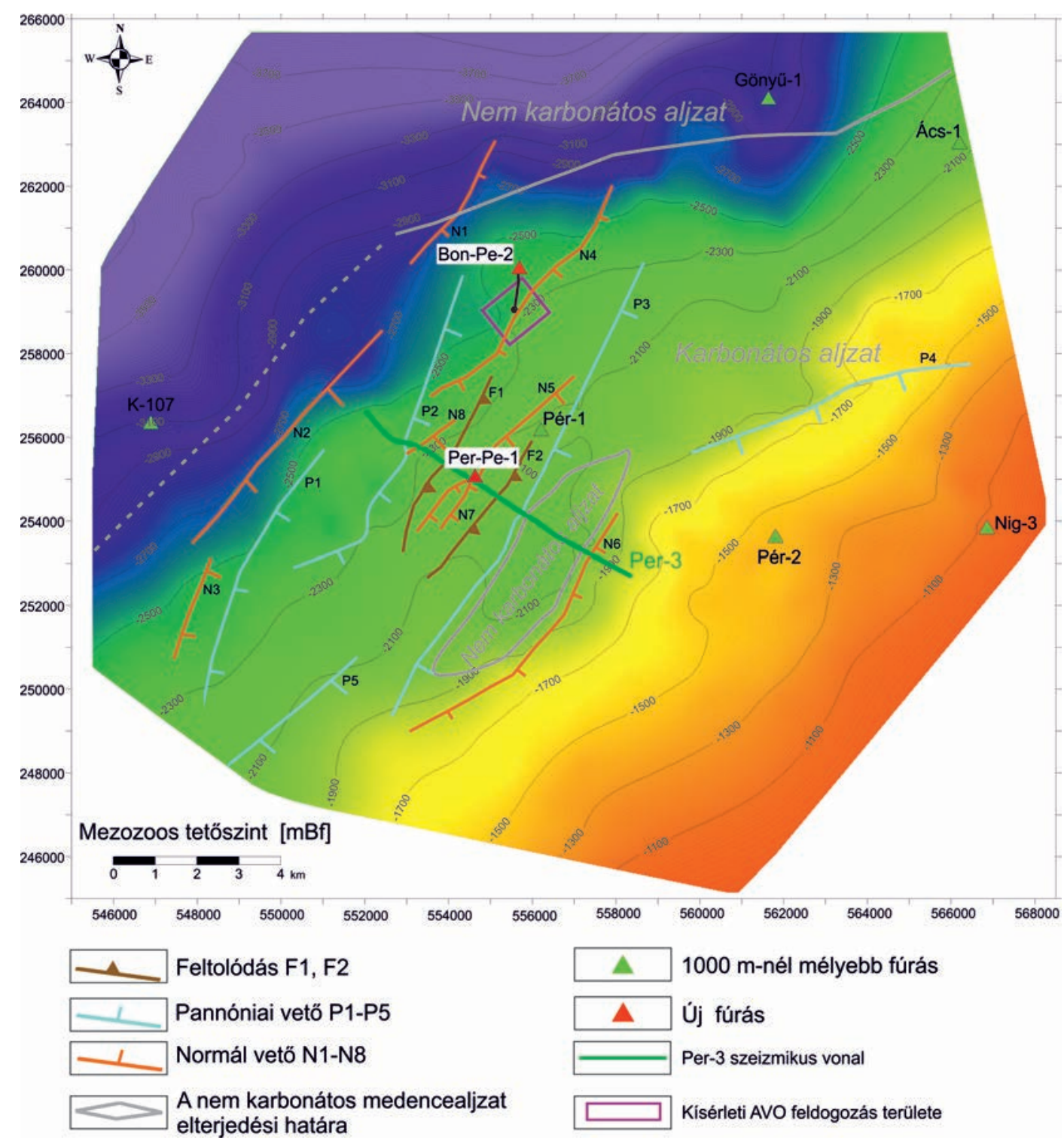

7. ábra. A kutatási terület prekainozoos medencealjzat mélységtérképe a főbb korrelált szerkezeti elemekkel

Figure 7. Isodepth map of pre-Cenozoic basement of the study area indicating the main correlated tectonic elements

CASTAGnA 2014). A számítógépes futási idők csökkentése érdekében a módszertani vizsgálatba bevont területet le kellett csökkenteni az eredetileg tanulmányozott térrész kisebb területére. Így egy olyan 1200×1200 m nagyságú terület állt elő, melynek hozzávetőlegesen a közepén helyezkedik el a Bon-Pe-02 jelú termelő kút (8. ábra). A triász korú medencealjzat tetőzónájának a skálázott Poisson-hányados változás AVO-attribútum térképén a szürke színú részek a Poisson-hányados jelentős mértékû csökkenését jelzik, ami értelmezésünk szerint porózus kőzettani formációkra utal. A kék színú területek tektonikailag igénybe vett gyengült zónákat, a narancssárga részek pedig tömörebb kőzettestet valószínúsítenek. Jól látható, hogy a Bon-Pe-02 jelú kút egy a környezetéhez képest lényegesen nagyobb porozitásúként jelzett (szürke színú) térrészben érte el az alaphegység tetőzónáját. Kezdeti eredményeinket biztatónak ítéljük az AVO-analízis geotermikus célú alkalmazását illetően, azonban ezeket még mélyfúrás-geofizikai adatok alapján történő modellszámításokkal és kalibrációval ellenőrizni kívánjuk.

A kutatás eredményeként két gazdaságilag sikeres geotermikus kútpár telepítése történt meg, a két a termelő kút esetében $300 \mathrm{~m}^{3}$ /óra szabadkifolyású és 600 m³\%óra mélyszivattyús víztermeléssel, illetve $100{ }^{\circ} \mathrm{C}$ és $105^{\circ} \mathrm{C}$ kifolyó hőmérséklettel.

\section{Borsodi szénmedence — vetókutatás}

\section{Geológia környezet és földtani kockázat}

A vizsgált terület a Nyugat-Borsodi-szénmedence részét képzi. A területen feltételezhetően triász aljzatra (HAAS et al. 2010) települő medencekitöltő 1000-1500 m vastag kainozoos üledéksor gazdaságföldtani szempontból legfontosabb képződménye a miocén korú Salgótarjáni Barnakő- 


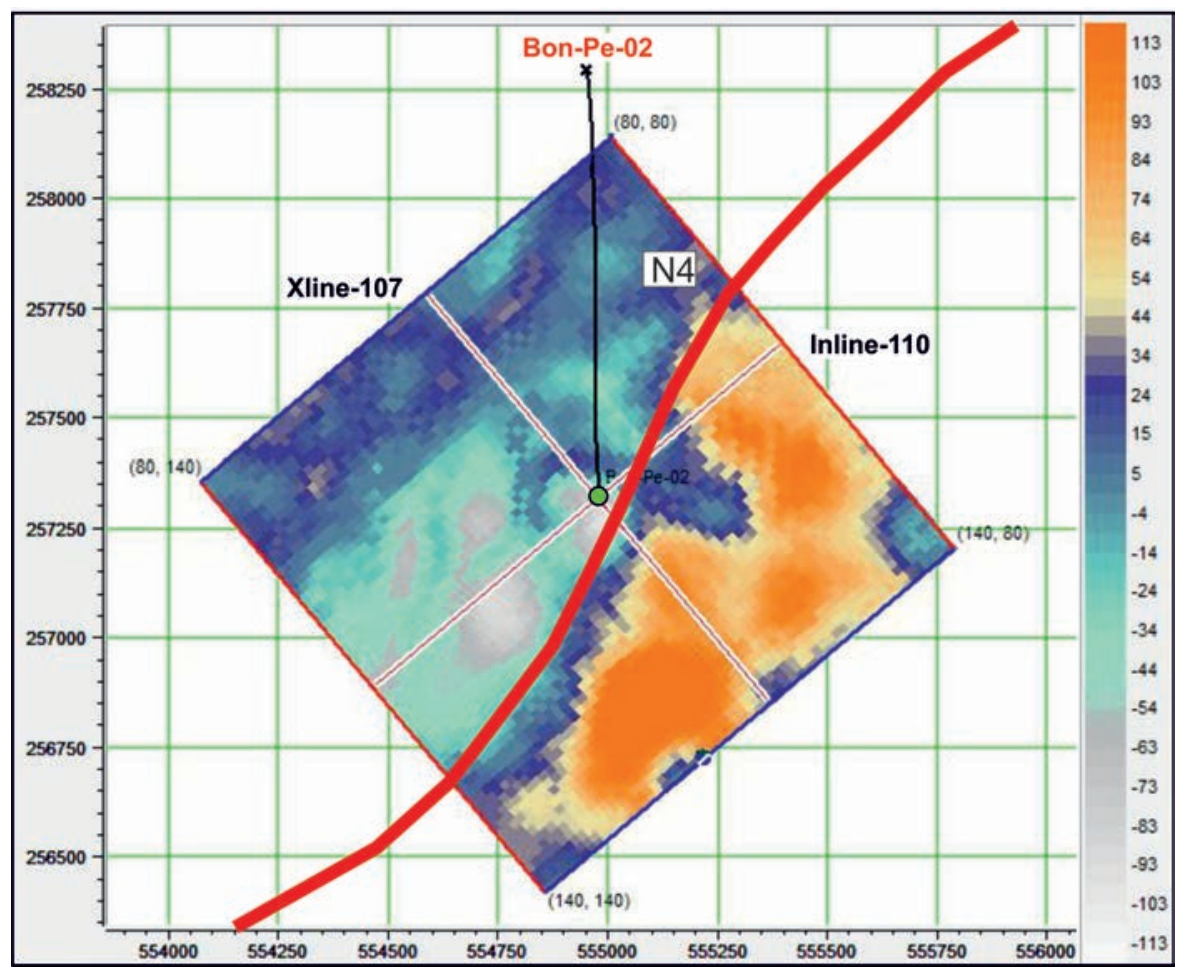

8. ábra. Skálázott Poisson-hányados változás AVO-attribútum a triász korú medencealjat tetőzónájában. A piros vonal a korábban kitérképezett N4 jelü vetőt jelzi

Figure 8. Scaled Poisson's ratio change AVO attribute at the uppermost zone of the Triassic basement. Red line marks N4 fault mapped previously

szén Formáció. A három telepet magába foglaló szenes összlet a kutatási területen 200-400 m mélységben helyezkedik el (ÁDÁm 2006, 2014, PÜSPÖKI et al. 2009). A borsodi széntelepes összlet kifejlődését biosztratigráfiai munkák az ottnangi-kárpátira teszik (KORECZ-LAKY 1985, BoHN-HAvas et al. 2000), azonban az újabb vizsgálatok a nyugat-borsodi előfordulás korát kárpátinak vélik (PÁLFY et al. 2007, PAlzer-Khomenko et al. 2019). Az összletet a Darnó-zóna fejlődéséhez kötődően többfázisú deformáció érte, melyet regionális léptékben SzTANó \& TARI (1993), FODOR et al. (2005), FODOR (2010), valamint PETRIK et al. (2016) és BeKE et al. (2019) részletez. A közvetlen kutatási területen feltételezhetô szerkezeti elemeket PÜsPÖKI 2017 interpretálta részletes karotázskorreláció alapján.

A területen történt jelentôs volumenú földtani kutatás ellenére a rendelkezésre álló ismeretanyag a korszerú kutatási módszereken alapuló nemzetközi elvárásokhoz képest elavult. A mai igények a korábbinál jóval nagyobb követelményeket támasztanak a földtani modellezés, különösen annak bizonytalansága meghatározása terén. Napjainkban a terület földtanában a legkevésbé ismert, így gazdasági szempontból a legnagyobb kockázatot jelentő tényezők a vetốk, valamint a széntelepes ciklusok kontinuitása. Ezek vizsgálatára közvetlen mérések korábban annak ellenére sem történtek, hogy a szeizmikus módszer ma már alkalmas lehet az ilyen irányú ismeretek bővítésére, a kockázatok csökkentésére.

Az MBFSZ 2019 februárjában kismélységú szerkezetkutató szeizmikus mérést végzett Sajómercse-Sajóvelezd térségében (9. ábra), melynek célja az volt, hogy a nagyfelbontású karotázskorreláció (PÜSPÖKI et al. 2017) pontszerú adatait, valamint azok földtani alapú megfontolásból történő térbeli kiterjesztését megerôsítse, további szerkezeti elemeket azonosítson, valamint pontosítsa a tektonikai elemek kinematikáját. A kapott eredmények a szerkezetkutatáson túl felhasználhatók további kockázatbecslésre/csökkentésre is, hiszen információt hordoznak a széntelepek folytonosságáról, valamint a vulkanitok esetleges betelepüléséról is.

\section{Alkalmazott módszer}

A szeizmikus eredményekre alapvetően támaszkodó elsô modern hazai szénkutatás a Mecsek területén 2009ben valósult meg (РüSPÖKI et al. 2012). Váralja térségében 2012-ben a szénkutatás támogatására 3D mérés is készült, azonban ennek a kb. $30 \mathrm{~m}$-es felbontóképessége csak a kutatási területet átszelő nagyobb, korrelálható vetősíkok, illetve a szenes összleteket befoglaló, genetikailag összetartozó üledékes testek értelmezését tette lehetôvé (KovÁcs 2012). Figyelembe véve az alkalmazott szeizmikus módszer elvi lehetôségeit, a mérések célja itt sem a 400 méteres mélységből ismert, 3-5 méteres széntelepek kimutatása és korrelálása volt, hanem a valamivel vastagabb széntelepes ciklusok térbeli leképzése, valamint a ciklusokat harántoló vetők detektálása. A megcélzott 400 méteres mélységtartomány megfelelő leképzéséhez a korábbi szeizmikus kutatások tapasztalatai alapján (HEGEDús 1984, Szalay 1985) 5 méteres geofon- és 5 méteres forrás- 


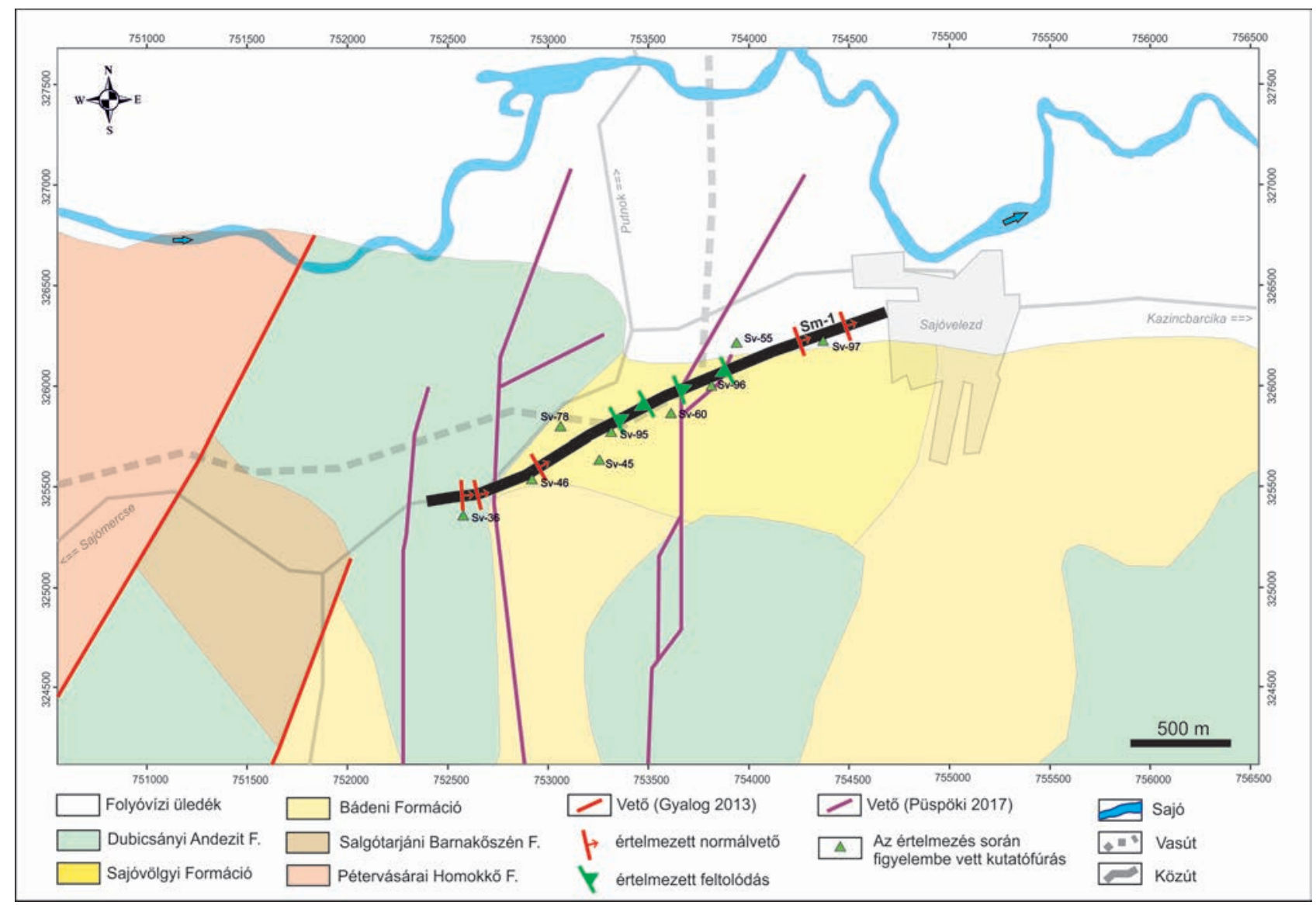

9. ábra. A 2019-ben mért reflexiós szeizmikus szelvény nyomvonala (Sm-1), földtani környezete (GYALOG 2013), valamint a felhasznált szénkutató fúrások elhelyezkedése. Az térképen feltüntettük a karotázskorreláció alapján feltételezett vetőket (PüsPöKI 2017) és a szelvény mentén értelmezett szerkezeti elemeket is

Figure 9. Location of Sm-1 reflection seismic line measured in 2019 and the used coal-exploration boreholes indicated on the geological map of the studied area (GYALOG 2013). Suspected faults based on log-correlation (PÜSPÖKI 2017) and interpreted tectonic elements in this study is also signed

ponttávolság mellett döntöttünk. Jelforrásként vibroszeiz rendszert alkalmaztunk változó számú (1-3 db), 20-130 Hz-es 16 másodperces lineáris sweep paraméter beállítással.

Az adatfeldolgozás során hagyományos múveletek követték egymást (frekvenciaszúrés, zavarhullámok elnyomása, AGC, dekonvolúció, statikus korrekció, sebességanalízis, maradék statikus korrekciók, NMO, összegzés, F-X dekonvolúció és migráció). Az egyes múveletek sorrendjét, valamint optimális paramétereit részletes tesztekkel határoztuk meg a lehetô legjobb minőségú szerkezeti kép és a legmagasabb felbontás elérése érdekében. A feldolgozás eredményeként kapott reflexiós P-hullám időszelvényeken elért vertikális felbontás 6-9 m (BAUER et al. 2019).

\section{Eredmény - Sm-1 szelvény és értelmezése}

A fenti módon előállított 2,4 km hosszú Sm-1 szeizmikus szelvény a megcélzott vizsgálati mélységtartományban (0-0,4 s időtartományban) alkalmas a tervezett földtani értelmezésre. A széntelepes rétegsor, annak közvetlen feküje és a fedő badeni rétegsor egyaránt követhető a korrelálható reflexiók segítségével (10. ábra). A szelvény szeizmikus jellegét tekintve két részre tagolódik: 14001600 m (szelvénymenti távolság) között jelentős tektonikusan zavart zóna észlelhetô, mely pozitív virágszerkezetként szeparálja a tőle keletre és nyugatra esô árokszerú térrészeket. A szelvény nyugati felén egy jól reflektáló üledékcsomagokkal kitöltött félárok jelenik meg, melynek nyugati peremét nagy, kb. 30 m-es elvetésekkel jellemezhető, keleties dőlésû normálvetők jelölik ki, melyek a fedő badeni képződményeket is elvetik. A szelvény keleti oldalán kiemelt helyzetben két kisebb árokszerú mélyedés helyezkedik el (1600 m-tôl a szelvény végéig), melyek az Sv-55 és Sv-97 fúrások szerint csak a szenes összlet alsó telepeit tartalmazzák.

A legjobban reflektáló felület — hasonlóan a '80-as évekbeli szénkutató szeizmikus szelvényekhez (HEGEDús 1984, Szalay 1985) — a szenes összlet és a feküje közti határfelület (Pétervásárai Homokkő Formáció tetôszint a 10. ábrán). Az Sm-1 időszelvényen elért nagy vertikális felbontás (6-9 m) azonban lehetővé tette a nagy amplitúdóval jelentkező szenes összlet további tagolását, valamint szelvény menti korrelálását is, amelyet a feltáró fúrásokban rendelkezésre álló nagyfelbontású karotázsértelmezések 


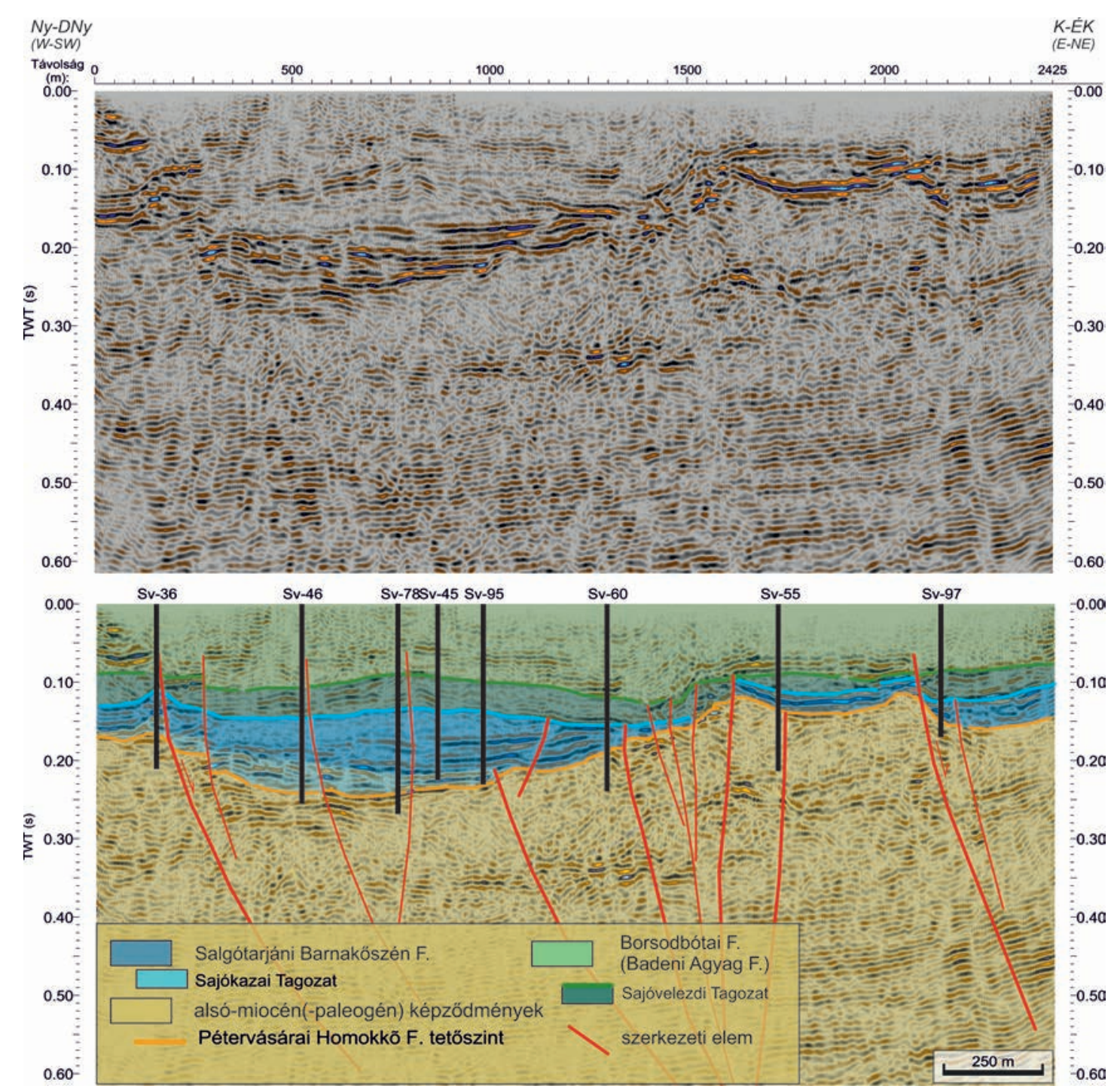

10. ábra. Sm-1 migrált reflexiós P-hullám időszelvény és annak értelmezése

Figure 10. Sm-1 time-migrated $P$ - wave reflection section and its interpretation

segítenek. A szelvény nyomvonalában a széntelepes összlet szerkezetileg tagolt; benne transzpresszióra utaló virágszerkezetek azonosíthatók (Sv-95 és Sv-60 fúrások közt), melyek 10-12 m-es elvetési magasságokat eredményezhetnek a telepes csoport szintjén.

A terület települési viszonyait alapvetóen meghatározó rétegszintkülönbséget mélyfúrások alapján korábban késôbadeni-szarmata normálvetô jelenlétével értelmezték (PüsPÖKI 2017) a telepes csoport és a badeni rétegek hasonló elvetési magassága alapján. A nagyfelbontású karotázskorreláció alapján feltételezett normálvetôk jelenlétét sikerült megerôsíteni, azonban az $\mathrm{Sm}-1$ szeizmikus szelvény lokálisan kompressziós - a barnakôszenes összlet képződésével egyidejű (vagy annál kicsit fiatalabb) — deformáció jelenlétére is utal. Ez nagy vonalakban beilleszthető a Darnó-zóna környezetéról kialakult tektonikai képbe, mely az ottnangi-korabadeni alatt balos eltolódásos lehetett (FODOR 2010). A félárok szerkezet felnyílása a D4 extenziós fázishoz (PETRIK et al. 2016, BeKE et al. 2019) köthető, ezzel egyidejúek vagy kicsit fiatalabbak a kompressziós deformációs elemek, majd az extenzió felújulása tapasztalható, mely már a fedő alsó-badeni üledékeket is elveti (D6, BEKE et al. 2019)

A fúrásokkal sûrún igazolt széntelepes összlet feltárási elképzeléseit és a megtervezett fejtési idomokat a szeizmikus mérés alapján kapott, a feltolódásos elemeket is tartalmazó szerkezeti kép is megerősíti, legfeljebb a szintek közötti kapcsolatok kialakításának pontos helyére vonatkozóan eredményezhet némi módosítást. Lényeges hatást gyakorol ugyanakkor a szerkezeti kép újraértelmezése a várható szerkezeti zavarok gyakoriságát és jellegét illetôen, hiszen az Sm-1 szelvény mentén számos eddig ismeretlen, a széntelepek vastagságával összemérhetố elvetésú vetôt sikerült kimutatni (9. ábra).

\section{Következtetések}

A három szeizmikus kutatás eltéró földtani környezetben és különböző kutatási mélységekből szolgáltatott példát arra, hogy a szénhidrogén-kutatásban rutinszerúen alkalmazott 
felszíni reflexiós szeizmikus kutatás más típusú, változatos földtani célokat megvalósító projektek sikeréhez is hozzájárulhat, lecsökkentve a földtani közeg heterogenitásából, illetve ismertségének bizonytalanságából adódó kockázatot.

Habár az alkalmazott reflexiós szeizmikus módszer elméleti alapjai minden esetben ugyanazok (MESKó 1977, YILMAZ \& DOHERTY 2001), a bemutatott példák is rávilágítanak arra, hogy a mérési paraméterek minden esetben egyedi és a kutatási célt szem előtt tartó gondos tervezést igényelnek. A szénhidrogén-kutatásnál kisebb volumenú földtani beruházásoknál, mint például a geotermikus kutatás, melynek jövedelemtermelő képessége kisebb, megtérülési ideje pedig hosszabb, fontos szempont a gazdaságosság, valamint az, hogy a kockázat már a kezdeti kutatási fázisban csökkenthető legyen. Mindezek indokolják, hogy a kutatási metodikában igen nagy hangsúlyt kell fektetni a minél szélesebb körú archív geológiai és geofizikai adatok beszerzésére, értékelésére, és szükség esetén, újrafeldolgozására és újraértelmezésére. Ezt követheti a feladat megoldását elősegítő új mérések tervezése és kivitelezése.

A Nyugat-Mecsek szeizmikus kutatása hosszú múltra visszatekintő együttmúködés keretében valósult meg a Mecsekérc Zrt. és a Magyar Bányászati és Földtani Szolgálat (illetve előd intézményei) együttmúködésében, így viszonylag sok és változatos szeizmikus adat áll rendelkezésre. Ezek sora az 1970-es évekbe mért szerkezetkutató Gö-1-7, -9 (KóNYA 1978), majd a Bodai Agyagkô Formáció kutatásának keretében a 2000-es évek elején mért Me-101-104 reflexiós szeizmikus szelvényektől (TóTH \& KovÁCs 2004) kezdve a 2004-ben a Nyugat-Mecsek központi részén, a Boda-Büdöskúti-vetőzóna és a Hetvehely-Magyarszékvetőzóna $\mathrm{kb} .50 \mathrm{~km}^{2}$-es környezetében átnézetes 3D szeizmikus tomográfiás mérésen (KovÁcs 2005) át az utóbbi évek Ibafa-4 és BAF-1 fúrásokban végzett szeizmikus sebesség vizsgálatokig terjed. Mindezen szeizmikus adatok beépültek a szerkezetkutatás legutóbbi, a terület nyugati, neogén üledékkel fedett részére összpontosuló szakaszában elért eredmények értelmezésébe.

A szeizmikus értelmezés alapján körvonalazhatók a keleti területeken felszíni térképezésből is ismert fő szerkezeti elemek (KonRÁd et al. 2016, MAJORos \& MENYHEI 2017, SEBE et al. 2017) nyugati irányú folytatásai (4. ábra B), a Goricai egységben pedig a BAF elterjedésének mind vertikális, mind horizontális határára becslés adható. A szelvények alapján az intenzív miocén szerkezeti mozgások jelentősége is megerôsíthetô a térségben.

Egy potenciális geotermikus mintaprojekt ajánlott kutatási stratégiáját tárgyaló tanulmány (KovÁcs 2017) is jelentôs kockázatcsökkentő tényezőnek írja le a szeizmikus módszert, de az csupán a már meglévő adatok értékelésére terjedt ki. A győri geotermikus projekt most bemutatott szeizmikus kutatása olyan gyakorlati példát szolgáltat, melyet gazdaságilag sikeres termelő-visszasajtoló kútpárok lemélyítése követett. Konkrét fúrási és próbatermelési adatok birtokában a győri projekt a hosszú távú kockázatok elemzésére, tehát az erőforrás esetleges kimerülésével kapcsolatos kockázatok vizsgálatára is alkalmas lehet.
A geotermikus kutatási célokra eddig ritkán használt AVO-elemzés olyan eredménnyel zárult, amely előrevetíti a sikeres alkalmazásának lehetőségét további kutatásoknál is. A Bon-Pe-2 fúrás körül kísérleti jelleggel kiválasztott 1,2×1,2 km-es területre számolt ún. skálázott Poisson-hányados változás térképen jelentôs anomáliák mutathatók ki (8. ábra). Értelmezésünk szerint ezek az anomáliák az ép és a mállott karbonátos kőzettestek porozitásbeli különbségeiként értelmezhetők, ugyanakkor ennek a feltevésnek az igazolásához további vizsgálatokra van szükség.

A hazai szénkutatás gyakorlatában a szeizmikus kutatások alárendelt szerepet kaptak, melynek oka, hogy a készletszámítások alapvetôen a sikeres telepharántolásokra támaszkodnak (PÜSPÖKI et al. 2018), a kismélységú, szerkezetileg is tagolt szenes összletek pedig többnyire erősen tagolt felszínformájú vidékeken, a szeizmikus mérések számára kedvezőtlen környezetben találhatók (SzALAY 1985, HEGEDƯs 1984). Ennek ellenére a nagyfelbontású szeizmikus méréseknek a szerkezeti viszonyok tisztázásában jelentős szerepük van (THOMAs 2013), elsősorban a telepes összletekben jelentkező szerkezeti zavarok jellegének meghatározásában.

A Sajómercse II. területen végrehajtott nagyfelbontású szeizmikus szelvényezés a karotázs-korrelációval összevethető 6-9 m-es felbontást eredményezett. A kutatás a nagyvonalakban ismert fô normálvetôs szerkezeteken túl számos kisebb, de a széntelepek vastagságával összemérhető elvetésú, eddig ismeretlen vetôt mutatott ki (10. ábra). A lokális transzpressziós tektonikából adódó laterálisan gyakoribb szerkezeti zavaroknak leginkább a frontfejtések telepítésére, a víztelenítés hatékonyságára, illetve a vízbetörés veszély előrejelzésének bizonytalanságára nézve van következménye (HAVELDA Tamás, szóbeli közlés). A kapott eredmények tehát ezeken a területeken csökkentik leginkább az esetleges bányászat földtani kockázatát.

Mivel az eredmények a Sajómercse II. területról alkotott szerkezeti képet módosítják, indokolt lehet a terület szerkezeti folytatásába eső, és a gazdaságos széntermeléshez szükséges Dubicsány terület esetében is hasonló vizsgálat elvégzése, valamint kiegészítő szeizmikus mérések tervezése. Egy északi vonal a Dubicsány szénkutatási terület szerkezeti viszonyait pontosítaná, míg egy déli vonal az Sm-1 vonal folytatásaként bekötné az archív Du-2 nagyfelbontású, illetve a regionális So-1 reflexiós szelvényeket a szeizmikus hálózatba, ezzel áttekintő képet adva a Darnó-zóna két pereméről.

Fontos kiemelni, hogy bár a bemutatott szeizmikus mérések minden esetben egy konkrét kérdés vagy kérdéskör megválaszolását célozták pontosabbá téve a kutatási terület földtani modelljét, ezzel egyidejúleg olyan jó felbontású és időtálló szeizmikus adatokat szolgáltattak, amelyek további — az alapkutatás témakörébe tartozó — értelmezésekhez is megfelelő alapot nyújtanak.

\section{Köszönetnyilvánítás}

A Nyugat-Mecsek szerkezetkutatásának eredményeit a Mecsekérc Zrt., illetve RHK jóváhagyásával közöltük. Kü- 
lön köszönettel tartozunk HÁMOs Gábornak a földtani környezet értelmezésében nyújtott segítségéért.

A péri geotermikus kutatás bemutatása a PannErgy Nyrt. hozzájárulásával történhetett meg.

A Sajó menti mérést a ZB78001 számú ITM támogatási szerződés finanszírozta. Munkánkat PÜSPÖKI Zoltán a Borsodi-szénmedence szakértője, illetve SzALAY István az 1970_ 90-es években végzett Bükk-előtéri szeizmikus mérések feldolgozásának és értelmezésének vezető kutatója segítette.
A terepi mérések kivitelezésében az MBFSZ munkatársai, többek közt TukA Sándor, Kun Lajos, GILI László, BERECZKI László és MARKOS Gábor múködtek közre.

Köszönjük lektoraink (UHRIN András, ÁDÁM László és egy anonim lektor) konstruktív hozzászólásait, amik nagyban hozzájárultak a kézirat fejlődéséhez és további vizsgálati lehetôségeket vetettek fel.

\section{Irodalom — References}

Aleardi, M. \& Mazzotti, A. 2012: A study on the seismic AVO signatures of deep fractured geothermal reservoirs in an intrusive basement. - EGU General Assembly, Geophysical Research Abstracts 14, p. 3043.

ÁDÁM L. 2006: A Darnó-öv hatása a borsodi széntelepes összletre. — Földtani Közlöny 136/1, 25-36.

ÁDÁM L. 2014: A borsodi kőszéntelepes összlet rétegtani problémái. — Általános Földtani Szemle 31, 33-50.

BAuer M., Cserkész-NAGY Á. \& TAKÁcs E. (szerk.) 2019: Kutatási jelentés a Sajómercse-Sajóvelezd, valamint Uppony-Bánhorváti térségében elvégzett szeizmikus mérésről. - Kézirat, Jelentés, MBFSZ, Budapest, 62 p.

Beke, B., Fodor, L., Millar, L., Petrik A. 2019: Deformation band formation as a function of progressive burial: Depth calibration and mechanism change in the Pannonian Basin (Hungary). — Marine and Petroleum Geology 105, 1-16. https://doi.org/10.1016/ j.marpetgeo.2019.04.006

BoDOKY T. \& Polcz I. 2016: Az Eötvös Loránd Geofizikai Intézet története II. — MFGI, Budapest, 726 p.

Bohnné HaVAs, M., NAgY, E., NAGY-Bodor, E., RadócZ, Gy., RÁKosi, L. \& SzEgő, É. 2000: Paleoenvironmental reconstruction of cyclic coal-bearing sequence in Borsod basin (N Hungary). — Geological Society of Greece, Special Publication 9, 37-42.

Cameli, G. M., Ceccarelli, A., Dini, I. \& Mazzotti, A. 2000: Contribution of the seismic reflection method to the location of deep fractured levels in the geothermal fields of southern Tuscany (Central Italy). — World Geothermal Congress, Proceedings, 1025-1029.

Chopra, S. \& CASTAGna, J. P. 2014: AVO. — Investigations in Geophysics 16, Society of Exploration Geophysicist, Tulsa, Oklahoma, 288 p. https://doi.org/10.1190/1.9781560803201

Cserkész-Nagy Á., TaKács E., Bauer M., Csabafi M., Gúthy T., Kóborné Bujdosó É., Kovács A.Cs., Szőts G. \& Hegedưs E. 2018: A Nyugat-Mecsek szeizmikus kutatásának legújabb eredményei: A Me-105 és Me-106 szelvények földtani értelmezése. — In: HÁmos G. \& SÁmson M. (szerk.): Bodai Agyagkő Formáció kutatás szakmai elóadói nap. — Magyarhoni Földtani Társulat, MTA Pécsi Akadémiai Bizottság, RHK Kft. kiadvány, Pécs, 72-80.

FANCSIK T., TóTH S., GYÖRGY L. \& NYÁRI Zs. 2010: Archív ELGI szeizmikus szelvények feldolgozása, értelmezése. — Kézirat, Kutatási jelentés, ELGI, Budapest.

FODOR L. 2010: Mezozoos-kainozoos feszültségmezők és törésrendszerek a Pannon-medence ÉNy-i részén — módszertani és szerkezeti elemzés. - Kézirat, Akadémiai doktori értekezés, Magyar Tudományos Akadémia, Budapest, 129 p.

Fodor, L., Radócz, Gy., Sztanó, O., Koroknai, B., Csontos, L. \& Harangi, Sz. 2005: Post-Conference Excursion: Tectonics, Sedimentation and Magmatism along the Darnó Zone. - GeoLines, 19, 142-162 p.

GöNZ G. \& RÁdLER B. 1985: A vertikális szeizmikus szelvényezés (VSP) alapjai. — Magyar Geofizika 26/2, 43-53.

GYALOG L. (szerk.) 2013: Magyarország földtani térképe 1:500 000. — MFGI, Budapest.

HaAs J., Budai T., Csontos L., Fodor L. \& KonRÁd Gy. 2010: Magyarország pre-kainozoos földtani térképe 1:500 000. — MÁFI, Budapest.

Hegedưs E. 1984: Jelentés a Felsőnyárád és Dubicsány térségben végzett reflexiós szeizmikus és elektromágneses mérésekről. — Kézirat, Jelentés, MÁELGI, Budapest, 16 p.

Horváth J., Hámos G., Benô D., Menyhei L., SÁmson M., Szamos I., Halász A. \& KonRád Gy. 2018: A BAF kutatási terület földtaniszerkezeti alapvonásai. In: Hámos G. \& SÁMSON M. (szerk.): Bodai Agyagkó Formáció kutatás szakmai elóadói nap. — Magyarhoni Földtani Társulat, MTA Pécsi Akadémiai Bizottság, RHK Kft. kiadvány, Pécs, 81-87.

JÄGER, R., MANN, J., HÖcht, G. \& HubRAL, P. 2001: Common-reflection-surface stack: image and attributes. — Geophysics 66, 97-109. http://dx.doi.org/10.1190/1.1444927

KIss J. (szerk.) 2003: Kutatási jelentés a BAF 2003 projekt keretében végzett gravitációs és mágneses mérések kivitelezéséről és értékeléséről. — Kézirat, Jelentés, ELGI, Budapest.

KonRÁD Gy. \& SEBE K. 2010: Fiatal tektonikai jelenségek új észlelései a Nyugat-Mecsekben és környezetében. — Földtani Közlöny 140/2, 135-162.

KonRÁD Gy., Sebe K. \& BudAi T. 2016: Magyarázó a Bodai Agyagkő Formáció perspektivikus elterjedési területének 1:25 000 méretarányú földtani térképéhez. — Kézirat, Mecsekérc Zrt., Pécs.

KoRECZnÉ LAKY I., (1985): A Kelet-borsodi medence ottnangi képződményeinek Foraminifera vizsgálata. — Geologica Hungarica series Palaeontologica 48, 180-237.

KovÁCs A. Cs. (szerk.) 2005: Átnézetes 3D szeizmikus tomográfiás mérések. — Kézirat, Előzetes kutatási jelentés, ELGI, Budapest. 
Kovács A. Cs. (szerk.) 2012: A Váralja kutatási területen elvégzett 3D szeizmikus mérés adatainak értelmezése és VSP feldolgozása. — Kézirat, Kutatási jelentés, Geofizikai Szolgáltató Kft. Budapest. 40 p.

KovÁcs A. Cs. (szerk.) 2017: Geotermikus energiahasznosításra potenciálisan alkalmas mintaterület vizsgálata Vecsés környezetében. — Kézirat, Tanulmány, MFGI, Budapest, 92 p.

KóNYA A. 1978: Geofizikai mérések a Mecsek hegység Ny-i részén (Királyegyháza-Korpád-Boda).—Kézirat, Kutatási jelentés, ELGI, Budapest, $13 \mathrm{p}$.

LŐRINCZ K. 2019: Szeizmikus attribútumok időmetszeteken történő vizsgálata — hogyan találjuk meg gyorsan a gáztartalmú homokköveket? - Magyar Geofizika 60, 20-29.

Majoros Gy. \& Menyhei L. 2017: Ny-Mecsek szerkezeti képének, térképének aktualizálása. — Kézirat, Mecsekérc Zrt., Pécs.

MazzotTi, A. \& MirRI, S. 1991: An experience in seismic amplitude processing. — First Break 9/2, 65-73. http://dx.doi.org/10.3997/ 1365-2397.1991004.

Meskó A. 1977: Szeizmikus mérések gyakorlati végrehajtása. — In: Meskó A. (szerk): Szeizmika I. Eötvös Loránd Tudományegyetem TTK, Budapest, 307-380.

Palzer-Khomenko, M., Wagreich, M., Knierzinger, W., Meszar, M. E. \& Gier, S. 2019: The early Miocene Calcite Minimum Interval: Pinning down upper Ottnangian Molasse stratigraphy. — AAPG Europe Regional Conference, Vienna. Abstracts, p. 39.

PÁlfy, J., Mundil, R., Renne, P. R., Bernor, R. L., Kordos, L. \& Gasparik, M. 2007: U-Pb and 40Ar/39Ar dating of the Miocene fossil track site at Ipolytarnóc (Hungary) and its implications. — Earth Planetary Science Letters 258, 160-174. https://doi.org/10.1016/ j.eps1.2007.03.029

Petrik A., Beke B., Fodor L. \& LukÁcs R. 2016: Cenozoic structural evolution of the southwestern Bükk Mts. and the southern part of the Darnó Deformation Belt (NE Hungary). — Geologica Carpathica 67, 83-104. https://doi: 10.1515/geoca-2016-0005

Polcz I. 2003: Az Eötvös Loránd Geofizikai Intézet története I. — ELGI, Budapest, 309 p.

PÜsPÖKI Z. (szerk.) 2017: Integrált szénmedence vizsgálatok. — Kézirat, Jelentés, MBFSZ, Budapest, 41 p.

PÜspöKi, Z., Tóth-Makk, Á., KoZÁK, M., DÁvid, Á., McIntosh, R. W., BudAY, T., DemETER, G., Kiss, J., PÜSPÖKI-TEREBESI, M., Barta, K., CsordÁs, Cs. \& KISS, J. 2009: Truncated higher order sequences as responses to compressive intraplate tectonic events superimposed on eustatic sea-level rise. — Sedimentary Geology 219, 208-236. https://doi.org/10.1016/j.sedgeo.2009.05.011

PÜspöKI, Z., Forgács, Z., Kovács, Zs., Kovács, E., Soós-Kablár, J., Jäger, L., Pusztafalvi, J., Kovács, Z., Demeter, G., McIntosh, R. W., KOZÁK, M. \& VerbőCI, J. 2012: Stratigraphy and deformation history of the Jurassic coal bearing series in the Eastern Mecsek. — International Journal of Coal Geology 102, 35-51. https://doi.org/10.1016/j.coal.2012.07.009

Püspöki, Z., Hámor-Vidó, M., Pummer, T., SÁri, K., Lendvay, P., Selmeczi, I., DetZky, G., Gúthy, T., Kiss, J., Kovács, Zs., Prakfalvi, P., McIntosh, R.W., Buday-Bódi, E., BÁldi, K. \& MArkos, G. 2017: A sequence stratigraphic investigation of a Miocene formation supported by coal seam quality parameters - Central Paratethys, N-Hungary. — International Journal of Coal Geology 179, 196210. https://doi.org/10.1016/j.coal.2017.05.016

PÜSPÖKi Z., Fogarassy-Pummer T., CserkéSZ-NAGy Á. \& MARKos G. 2018: 2. Módszertani fejlesztési lehetőségek a hazai szénkutatási gyakorlatban. - In: PÜSPÖKI Z., DeBreCZENI Á., FANCSIK T., HÁMORNÉ VIdó M. \& ZELEI G. (szerk.): A hazai szénvagyon és hasznosítási lehetôségei. MBFSZ, Budapest, 21-27.

Sebe K., Said D., WÁgenhoffer A., Hámos G., Kovács L., Somodi G., BőGÉr Á., Konrád Gy., Horváth J. \& Szujó G. 2017: Neotektonikai folyamatok alakulása a BAF tágabb földtani környezetében a késô-miocén óta. — Kézirat, Mecsekérc Zrt., Pécs.

SZALAY I. 1985: A Borsodi-medence barnakőszén előkutatási programja 1982-85 keretében a Medenceperem-Ny területen és BalatonSzilvásvárad környékén 1983-84-ben végzett geofizikai mérésekről. — Kézirat, Jelentés, MÁELGI, Budapest, 26 p.

SzTANó, O. \& TARI, G. 1993: Early Miocene basin evolution in Northern Hungary: Tectonics and Eustacy. — Tectonophysics 22, 485502. https://doi.org/10.1016/0040-1951(93)90134-6

TAKÁCs E. 1996: Az észlelési távolságtól függő amplitúdók analízise (AVO) és a hazai alkalmazás lehetőségei. — Magyar Geofizika 37, 154-169.

TAKÁCS E. (szerk.) 2018: Földtani kutatás a Nyugat-Mecsekben; Refrakciós és reflexiós szeizmikus szelvényezés, valamint feldolgozási eredmények a Me-105 és Me-106 vonalak mentén. — Kézirat, Kutatási jelentés, MBFSZ, Budapest, 54 p.

TAKÁCs E. \& CsERKÉSZ-NAGY Á. (szerk.) 2018: Földtani kutatás a Nyugat-Mecsekben; Közös reflexiós felületen (CRS) alapuló összegzés, mélység migráció, valamint mélységtartománybeli előzetes értelmezés a Me-105 és Me-106 szeizmikus szelvények mentén. — Kézirat, Kutatási jelentés, MBFSZ, Budapest. 30 p.

TAKÁCs, E., Kummer, I., Sipos, J. \& PÁPA, A. 2001: Bright spot analysis within the Pannonian Basin using horizon velocity estimation and Hilbert and AVO attributes. — First Break 17/3, 79-85. https://doi.org/10.1046/j.1365-2397.1999.00701.x

TARI, G. 1994: Alpine Tectonics of the Pannonian basin. - Manuscript, PhD thesis, Rice University, Texas, USA, 501 p.

Thomas, L. 2013: Geophysics of coal. — In: Thomas, L.(szerk.): Coal Geology (second edition). Wiley-Blackwell, Chichester, 211-252. https://doi.org/10.1002/9781118385685.ch8

TótH S. \& KovÁCs A. Cs. (szerk.) 2004: Kutatási jelentés a BAF 2003 projekt keretében végzett szeizmikus mérések kivitelezéséről és értékeléséről. - Kézirat, Jelentés, ELGI, Budapest 53 p.

Tungli Gy. \& Molnár P. 2018: A Bodai Agyagkő Formáció földtani kutatása. — In: Hámos G. \& SÁmson M. (szerk.): Bodai Agyagkő Formáció kutatás szakmai elóadói nap. — Magyarhoni Földtani Társulat, MTA Pécsi Akadémiai Bizottság, RHK Kft. kiadvány, Pécs, 1-8.

YILMAZ, O. 1999: When Reflections are not Hyperbolas and Reflectors are not Points, _ Journal of Applied Geophysics 42, $139-141$. https://doi.org/10.1016/s0926-9851(99)00034-8

YilmaZ, O. \& DoheRTY, S. M. 2001: Seismic data analysis: Processing, inversion, and interpretation of seismic data (2nd Edition) Investigations in Geophysics 10, 67-124. https://doi.org/10.1190/ 1.9781560801580

Kézirat beérkezett: 2019. 08. 05. 